\title{
Commute Trip Reduction in Washington: \\ Base Year Worksite \\ Characteristics and Programs
}

\section{RECRUED MUL 23 M O STI}

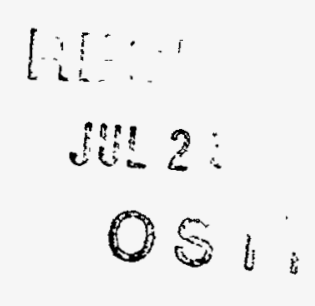

Prepared by: Dan Dodds

Washington State Energy Office 925 Plum Street SE

P.O. Box 43165

Olympia, WA 98504-3165

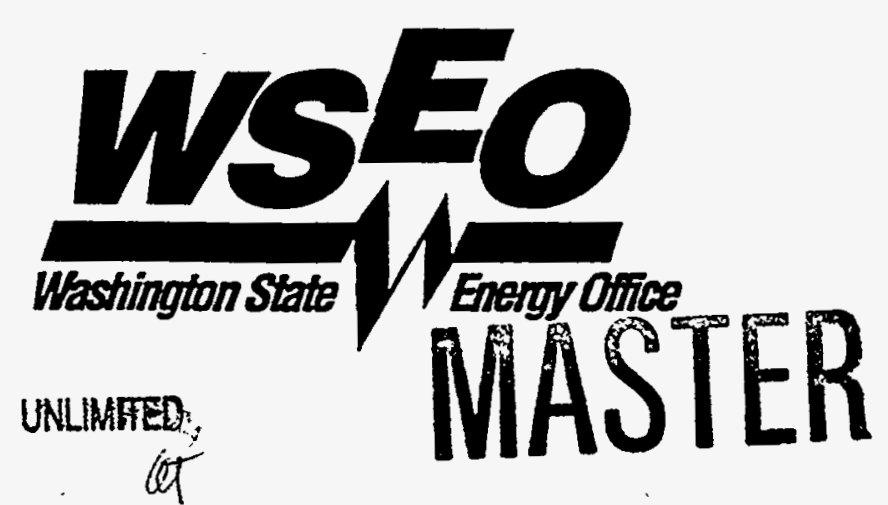




\section{ERRATUM}

On Page 18, the formula for potential trips should be

POTENTIAL_TRIPS $=5.0-D A Y S_{-} N O T \_W O R K E D-I N V A L I D \_R E S P O N S E S$ 


\section{DISCLAIMER}

Portions of this document may be illegible in electronic image products. Images are produced from the best available original document. 


\section{Contents}

Introduction

The Commute Trip Reduction Law

Task Force Actions So Far

State, County, and Local Support to Employers

This Report in Context

Employer and Worksite Descriptions

SOV and VMT Rates

18

Definitions and Calculation Methods

Pre-CTR SOV and VMT

SOV and VMT Reduction Goals

Mode Splits and Commute Trip Lengths

First Year Program Descriptions

Coverage

Employee Transportation Coordinators

Information and Promotion

Carpooling and Vanpooling

Work Scheduling and Telecommuting

Use of Company Vehicles

Parking Management

Facilities to Support Non-SOV Commuting

Subsidies and Incentives

TMA Membership

Next Steps 
This document wi1l be made available through the National Technical Information Service. 


\section{Tables}

Table 1 Affected Worksites, Program Descriptions, and Employee Surveys in Eight Counties 5

Table 2 Affected Worksites, Program Descriptions, and Employee Surveys in CTR Zones 10

Table 3

Table 4

Table 5

Size Distribution of Employers

Distribution of Number of Employers by Size of Employer 11

Table 6

Distribution of Worksites by Industry

Worksites Reporting Employee Parking $\quad 12$

Table 7

Table 8

Parking Spaces Per Employee

12

Employer Parking Spaces per Employee $\quad 13$

Table 9

Public Parking Near Affected Worksites

13

Table 10

Transit Service to Affected Worksites

Table 11

Table 12

Worksites Reporting Sidewalk Access

Worksites Reporting Nearby Bike Lanes

Table 13

Worksites Reporting Bicycle Parking

Table 14

Worksites Reporting Employee Lockers

Table 15

Worksites Reporting Employee Showers

Table 16

Worksites Reporting Resturants Nearby

Table 17

Worksites Reporting Shopping Nearby

Table 18

Worksites Near Other Employers

Table 19

Worksites With Multiple Shifts

Table 20

Sites Where Some Employees Also Work at Other Sites

Table 21

Sites Where Employees Need Own Car

Table 22

Worksites With Employees On Call

Table 23

Average SOV Rates

Table 24

Table 25

Worksite SOV Rates

Average VMT 22

Table 26

Worksite VMT

$\begin{array}{lll}\text { Table 27 } & \text { SOV Rates With and Without 20\% Credit } & 24 \\ \text { Table 28 } & \text { VMT With and Without 20\% Credit } & 25\end{array}$

Table 29 SOV Goals 26

Table 30 VMT Goals $\quad 27$

Table 31 Employee Commute Modes Percentages 28

Table 32 Average Commute Distances 28

Table 33 Employee Commute Modes by Zone Percentages ‘ 29

Table 34 Average Commute Distances by Zone 30

Table 35 Worksite CTR Information Dissemination 32

Table 36 Worksites With Ridesharing Programs · 32

Table 37 Worksites Using Employee Scheduling in CTR 32

Table 38 Worksites Using Company Vehicles for CTR 33

Table 39 Worksite Parking Management . 33

Table 40 Worksite Non-SOV Facilities

Table 41 Worksites Offering Non-SOV Subsidies

Table 42 Average Non-SOV Subsidies 34 


\section{Figures}

Figure 1 Counties State Map

Figure 2 Commute Trip Reduction Zones

Figure 3 Commute Trip Reduction Zones

Key for Figures 2 and 3
6

7

8

9 


\section{Introduction}

Employers in Washington's eight most populous counties are engaged in an effort to reduce their employees' use of single occupant automobiles for commuting. This report documents the status of those employers at the beginning of the Commute Trip Reduction (CTR) program as a basis for evaluating the impacts of the program.

The first section provides a brief exploration of the Washington CTR Law and a history of the first steps in its implementation. The second section presents a summary of the characteristics of the worksites affected by the law. The CTR Law calls for reductions in single occupant vehicle (SOV) commuting and in vehicle miles traveled (VMT). The third section of this report presents baseline measurements of SOV and VMT and goals for reducing them. The fourth section provides summary information on the first year of programs employers planned to implement. The final section very briefly outlines actions the Commute Trip Reduction law calls for between 1995 and 1999.

\section{The Commute Trip Reduction Law}

The Washington CTR Law was passed by the legislature in 1991 as part of the Washington Clean Air Act. The law had three purposes - to reduce air pollution, to reduce highway congestion, and to reduce reliance on imported oil. The legislature intended to accomplish these purposes by reducing the number of commute trips made in SOVs.

The CTR law affects only large employers in the state's eight largest counties. It requires each county with population of at least 150,000 to adopt a CTR plan as a county ordinance and to implement its plan. In each of the eight affected counties, the law requires every employer with at least 100 full time. employees at a single worksite who arrive at work between 6:00 a.m. and 9:00 a.m. to develop and implement a CTR plan for these employees. The CTR law exempts higher education institutions, seasonal employers, and construction worksites where construction will last less than two years. The law requires every city and town in the eight affected counties that has at least one affected worksite within. its boundaries to adopt a CTR plan as a city or town ordinance. The law also requires the Department of General Administration to develop a uniform CTR program for state agency worksites that are affected by the law.

The county, city, and town CTR plans must set goals for reducing the fraction of commute trips that affected employees make in SOVs and their average vehicle miles traveled (VMT) in commuting. The law requires goals for reductions in SOV rates and VMT of at least:

- 15 percent by 1995 , 25 percent by 1997 , and 35 percent by 1999.

The CTR law gives counties, cities and towns, and employers considerable leeway in designing CTR programs. To assist them in developing programs, and in revising programs that do not produce the targeted reductions, the CTR law created a support and evaluation structure consisting of a CTR Task Force and a state Technical Assistance Team.

\footnotetext{
' RCW 70.94.521-551. RCW 43.01.220-235, and RCW 43.42.140. 
The CTR law specifies two broad areas of responsibility for the CTR Task Force. It is to establish guidelines for implementation of the law by counties, local jurisdictions, and employers. The Task Force is also to evaluate the CTR law and its results and report back to the legislature. The law specifies four areas for the Task Force to evaluate. They are:

- Options for employers not covered by the CTR law, including whether the law should be extended to cover employers with 50 full time employees;

- Progress toward meeting the SOV and VMT reduction goals;

- Benefits and costs of the CTR program, where benefits include costs that would be incurred if there were no program; and

- The need to continue, modify, or terminate the program.

The CTR Task Force is to-report and make recommendations to the legislature on December 1, 1995 and December 1, 1999. The Task Force sunsets on July 1, 2000.

The CTR law specifies that the Task Force is to have 23 members consisting of:

- Five state agency hearis or their designees. with the Washington State Energy Office (WSEO) director as chair;

- Three transit agency representatives;

- Three county representatives;

- Three city and town representatives;

- Six employer representatives; and

- Three citizens.

The Technical Assistance Team (TAT) is to provide technical assistance to counties, cities and towns, state agencies, and other employers in complying with the CTR law. The TAT also serves as staff to the Task Force. The law specifies that the TAT will be under the direction of WSEO and will include representatives from the Department of Transportation and the Department of Ecology.

The CTR law directs that funds appropriated to implement the CTR law shall go to support the Task Force and the TAT, and to counties, cities, and towns in proportion to the number of affected worksites in each jurisdiction.

\section{Task Force Actions So Far}

The CTR Task Force held its first meeting October 4, 1991. The Task Force divided itself into three subcommittees to begin developing guidelines for implementing the CTR law. One subcommittee developed a model CTR ordinance. Another developed model programs and addressed parking issues and the training of Employee Transportation Coordinators (ETCs) for each worksite. The third subcommittee defined methods for measuring SOV and VMT rates and developed workplans for evaluating the CTR process. The Task Force and subcommittees developed draft implementation guidelines which the Task Force approved on February 28, 1992.

The Task Force presented the draft guidelines at a series of workshops for employers, local jurisdictions, and the general public around the state in March 1.992. In April and May of 1992, the Task Force held comment and testimony sessions and accepted 117 written comments. The Task Force revised the draft guidelines in response to the public comments and adopted the final implementation guidelines on June 5, 1992. 
Following adoption of the guidelines, the Task Force continued to meet quarterly, and the subcommittees met frequently to discuss issues including training, evaluation, survey development, program reporting forms, consistency across jurisdictions, and legislative issues. During this period, several original Task Force members left the group, and the Governor appointed replacements as specified in the CTR law.

At its October 1993 meeting, the Task Force turned its attention to the task of evaluating the CTR law for the legislature. The Task Force instructed the staff to develop a new committee structure, and in April 1994, the Task Force restructured itself into three subcommittees: the Impact Subcommittee, the Process Subcommittee, and the Policy.Subcommittee.

Each new subcommittee is responsible for implementing. one or more of the evaluation workplans. The Impact Subcommittee is responsible for evaluating SOV and VMT goal attainment and attainment of the policy goals of reduced energy consumption, reduced air pollution, and reduced congestion. The Process Subcommittee is evaluating participation, compliance, consistency across jurisdictions, technical assistance, training, and promotion. The Policy Subcommittee is evaluating potential modifications to the CTR law and alternative means of achieving the law's policy goals.

The subcommittees plan to complete their workplans and present preliminary reports to the Task Force as a whole by July 1995 . The Task Force will make a comprehensive report to the legislature in December 1995.

\section{: State, County, and Local Support to Employers}

After examining the experiences of other states, the Task Force concluded that a comprehensive training program would be vital to successful implementation of the CTR law. In the Spring of 1992, WSEO contracted with a consultant to develop five standard training courses. These courses had different target audiences and covered different aspects of the CTR program. An orientation course for local governments and employers was developed to familiarize them with the law and gain their commitment to the CTR program. A Basic CTR Training course introduced the CTR law, the Guidelines developed by the Task Force, and procedures for implementing the law at the local level. The Task Force requires this course as part of the certification process for local officials who will train others or review employers' CTR programs. Persons wanting to be certified by the Task Force to train others must complete an Instructor Training Course. Another course prepares program reviewers to review employer programs and annual progress reports. The Task Force requires program reviewers to pass a certification exam. ETC training provides worksite ETCs with the skills to develop, manage, and evaluate an effective CTR program.

All of these courses were conducted early in 1993 to produce a core group of trained CTR instructors. The trained local jurisdiction representatives conducted locally customized ETC training sessions throughout the remainder of 1993 . The TAT coordinated the program reviewer and instructor training courses.

The eight counties affected by the CTR law formed an eight-County Coordinating Group in September 1992. This group has met regularly to share information and discuss issues relating to the implementation of the CTR law. In its first year, the eight-County Group discussed the mechanics of the employee survey, the role of the counties in CTR and their relationships with local jurisdictions, the adoption of local CTR ordinances and plans, and outreach to employers.

The eight-County Coordinating Group also provides a forum for the county coordinators to provide information to the TAT. 


\section{This Report in Context}

This report has three functions:

- It shows the pre-CTR situation, particularly SOV rates and VMT, as a basis for evaluating the impacts of the program.

- It provides a catalog of program elements that employers planned to implement in the first year of the CTR program.

- It provides information on differences in pre-CTR commuting behavior that may be useful in designing and implementing CTR programs.

During an eighteen month period in 1993 and 1994, affected employers developed CTR programs. Employers provided two types of information to their local jurisdictions, the counties and the state. The first was an initial program description. In most cases, employers provided their program description on a form developed by the TAT and evaluation staff or on one of several forms designed by counties. Some employers only provided narrative descriptions. The initial program descriptions provided varying levels of detail about the worksite and the employer. The second type of information was on employee commuting behavior. In most cases. employers administered a survey developed under the gurdance of the Task Force. A few employers provided equivalent information collected in another way.

: Local jurisdictions set goals for SOV and VMT reductions based either on the initial survey results or on modeled estimates of initial SOV and VMT. A second employee survey is being administered during late 1994 and early 1995. This second survey will be used to determine whether the goals for 1995 have been met. The survey process will be repeated to track progress toward the 1997 and 1999 goals.

This report is based on the first year of employer program descriptions and employee surveys. It does not present any information on the results of the CTR program. The first year's results will be presented in the Task Force's report to the legislature in December 1995. The report to the legislature will document whether goals for 1995 were met. An interim report. planned for the Spring of 1995, will analyze the impact of worksite and employee characteristics on employee commute mode choices. That report will provide a foundation for the analysis of the impacts of CTR programs to be presented in the report to the legislature. 


\section{Employer and Worksite Descriptions}

Eight counties in Washington currently have populations above the threshold of 150,000 in the CTR law. The eight affected counties are shown in Figure 1.

The information in this report is drawn from two sources: employers' initial program descriptions and employee surveys. Employer program descriptions provided information about the worksite and the employer's CTR program. Employee surveys asked about commuting behavior. These two data sources cover slightly different sets of employers and employees. In addition, the employer program descriptions followed at least six different shared formats, and some were idiosyncratic. Because of this, information that was collected about some worksites was not collected about others. Throughout this report, employers' responses to questions will be accompanied by the number asked to provide the information.

Table 1 shows the number of affected employers in each county, the number of employer reports in WSEO's database, and the number of employers represented in the employee survey database. The numbers differ for several reasons. Some worksites completed program description forms even though they fell under the 100 full time employee cutoff or had been granted an exemption by their local jurisdiction. Some program descriptions have not yet been recorded in WSEO's database. Not all affected worksites surveyed their employees, and some worksites surveyed their employees but were not required to file a program description.

Table 1

Affected Worksites, Program Descriptions, and Employee Surveys in Eight Counties

\begin{tabular}{lcccc}
\hline County & $\begin{array}{c}\text { Affected, Non-Exempted } \\
\text { Worksites }\end{array}$ & $\begin{array}{c}\text { Program Descriptions in } \\
\text { WSEO Database }\end{array}$ & $\begin{array}{c}\text { Worksites That } \\
\text { Surveyed }\end{array}$ & $\begin{array}{c}\text { Surveys } \\
\text { Returned }\end{array}$ \\
\hline Clark & 41 & 41 & 42 & 12,440 \\
King & 477 & 487 & 340 & 77,918 \\
Kitsap & 23 & 18 & 32 & 18,401 \\
Pierce & 82 & 71 & 85 & 23,927 \\
Snohomish & 50 & 44 & 51 & 16,017 \\
Spokane & 64 & 65 & 77 & 20,434 \\
Thurston & 59 & 66 & 104 & 18,294 \\
Yakima & 23 & 15 & 25 & 4,009 \\
Total & 819 & 807 & 756 & 191,440 \\
\hline
\end{tabular}

SOV and VMT reduction goals are set for zones with similar characteristics, such as population and employment density. The eight counties are divided into twenty-six zones. These zones are shown in Figures 2 and 3. 
Figure 1

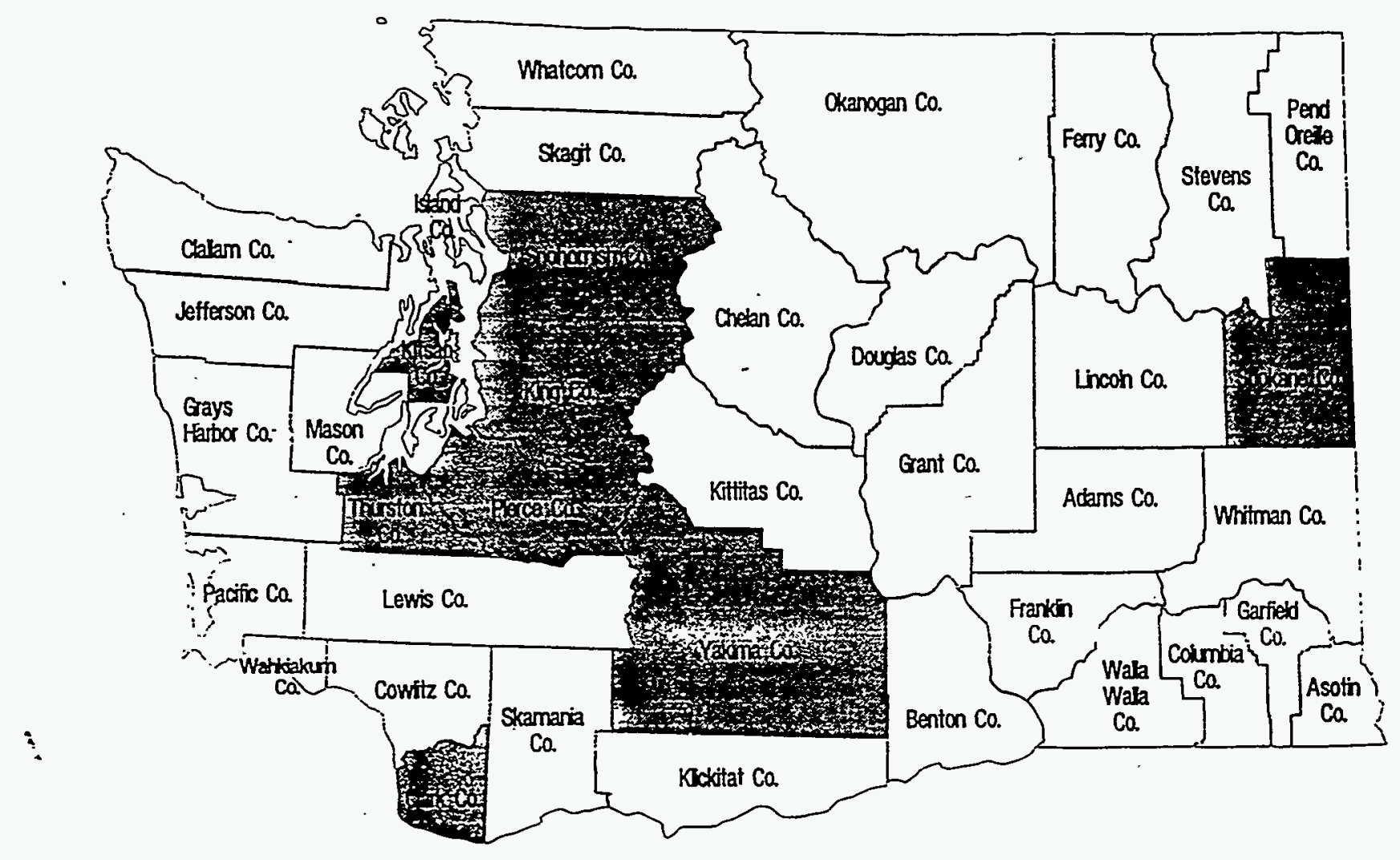


Figure 2
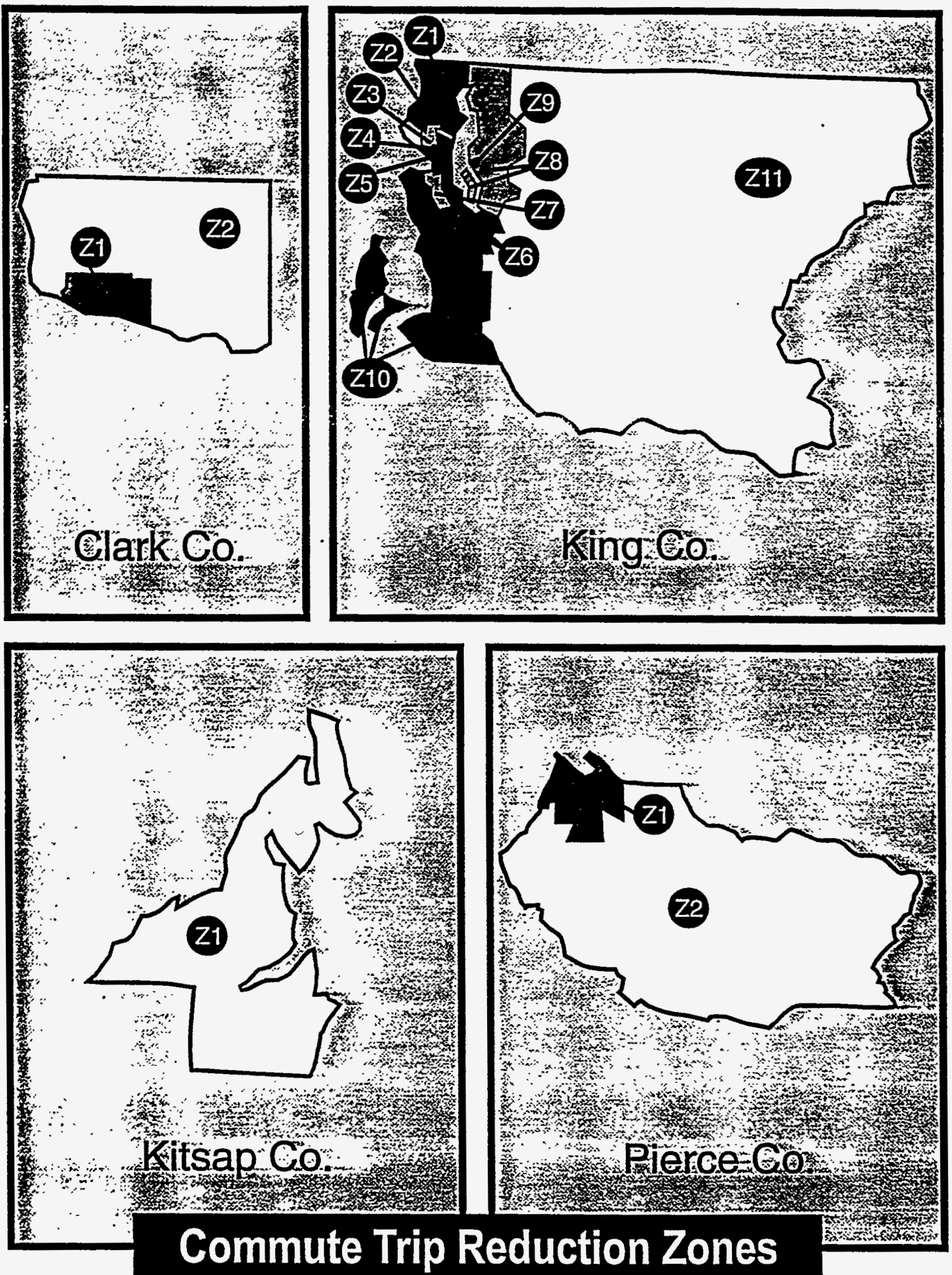
Figure 3
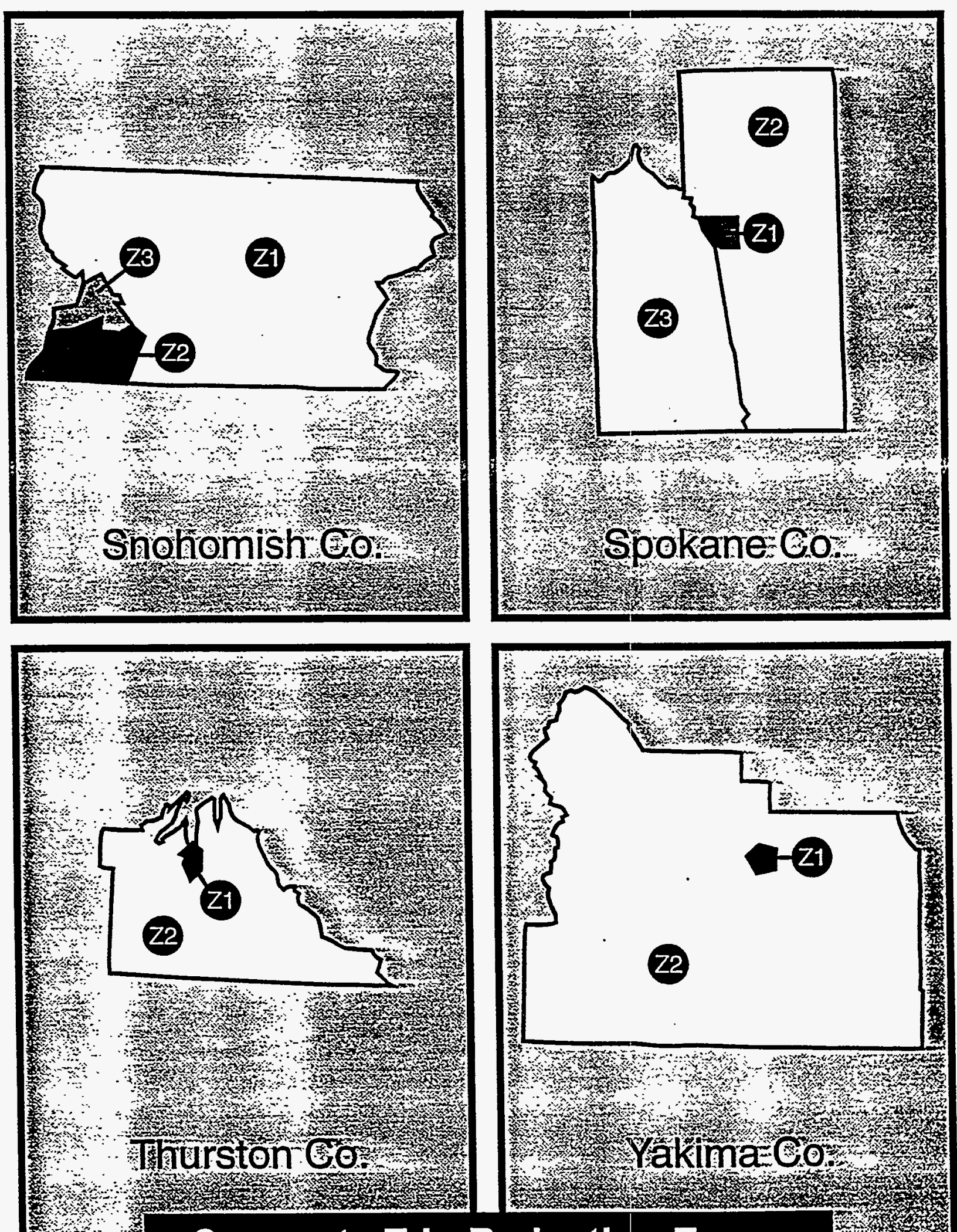

\section{Commute Trip Reduction Zones}


Key For Figures 2 And 3

County. Zone Name

Clark

Clark County Zone 1 (Urban)

Map Key

Clark

Clark County Zone 2 (Non-Urban)

King

North King County

$\mathrm{Z2}$

King

King

King

King

King

King

King

King

North Seattle

$\mathrm{Z} 1$

$\mathrm{Z3}$

Central Seattle

Seattle Central Business District

$\mathrm{ZA}$

South Seattle (Split Zone)

$\mathrm{Z5}$

Duwamish

$\mathrm{Z} 6$

East King County

Bellevue Central Business District

$\mathrm{Z7}$

King

South King County

Z9

King

Kitsap

Rural King County

$\mathrm{Z10}$

Kitsap County Zone

Z11

Pierce

Central Pierce County Zone (Tacoma-Fife Zone)

$\mathrm{Zl}$

Pierce Rural Pierce County Zone (Outer County)

$\mathrm{Z1}$

Snohomish

Rural Snohomish County

$\mathrm{Z} 2$

Snohomish

Southwest Snohomish County Zone

$\mathrm{Z} 1$

Snohomish

Spokane

Central Snohomish County Zone

$\mathrm{Z3}$

Spokane County Zone $1 \quad$ Z1

Spokane County Zone 2

Spokane County Zone $3 \quad$ Z3

Thurston County Zone 1 Z1

Thurston County Zone $2 \quad$ Z2

Yakima County Zone 1 (within Yakima city limits) Z1

Yakima County Zone 2 (outside Yakima city limits) $\quad$ Z2 
Table 2 shows the same information as Table 1 broken out by CTR zones.

Table 2

Affected Worksites, Program Descriptions, and Employee Surveys in CTR ZONES

Zone Name

Affected, Non-
Exempted
Worksites

Exempted

Worksites

\begin{tabular}{ccc} 
Program & Worksites & Surveys \\
Descriptions in & That & Returned \\
WSEO & Surveyed & \\
Database & & \\
\hline
\end{tabular}

Clark County Zone 1 (Urban)

Clark County Zone 2 (Non-Urban)

North King County

North Seattle

North Central Seattle

Central Seattle

Seattle Central Business District

South Seattle (Split Zone)

Duwamish

East King County

Bellevue Central Business District

South King County

Rural King County

Kitsap County Zone

Central Pierce County Zone (Tacoma-Fife Zone)

Rural Pierce County Zone (Outer County)

Rural Snohomish County

Southwest Snohomish County Zone

Central Snohomish County Zone

Spokane County Zone 1

Spokane County Zone 2

Spokane County Zone 3

Thurston County Zone 1

Thurston County Zone 2

Yakima County Zone 1 (within Yakima city limits)

Yakima County Zone 2 (outside Yakima city limits)

Unknown

\begin{tabular}{rrrr}
31 & 32 & 33 & 9,794 \\
10 & 9 & 9 & 2,646 \\
6 & 6 & 6 & 1,415 \\
22 & 24 & 14 & 3,271 \\
32 & 35 & 29 & 6,182 \\
31 & 32 & 22 & 5,408 \\
105 & 105 & 74 & 22,509 \\
15 & 13 & 7 & 2,150 \\
32 & 33 & 24 & 4,008 \\
94 & 97 & 67 & 12,374 \\
12 & 13 & 7 & 1,619 \\
113 & 118 & 82 & 17,924 \\
11 & 11 & 8 & 1,058 \\
23 & 18 & 32 & 18,401 \\
55 & 53 & 57 & 14,594 \\
27 & 18 & 28 & 9,333 \\
7 & 5 & 6 & 1,187 \\
19 & 14 & 16 & 5,269 \\
28 & 25 & 29 & 9,561 \\
28 & 29 & 33 & 9,380 \\
26 & 24 & 29 & 6,409 \\
10 & 12 & 15 & 4,645 \\
27 & 37 & 35 & 7,682 \\
32 & 29 & 46 & 8,701 \\
12 & 9 & 13 & 2,516 \\
11 & 33 & 12 & 1,493 \\
& & 23 & 1,911 \\
\hline
\end{tabular}

Table 3 shows the number of worksites with different numbers of affected employees in eàch of the eight counties. Most affected employers are relatively small. Eighty-five percent of affected worksites have 500 or fewer employees. Fifty-four percent have 200 or fewer affected employees.

Table 3

Size Distribution of Employers

\begin{tabular}{|c|c|c|c|c|c|c|c|c|c|c|c|c|}
\hline County & $<500$ & $\begin{array}{l}501- \\
1000\end{array}$ & $\begin{array}{c}1001- \\
1500\end{array}$ & $\begin{array}{l}1501- \\
2000\end{array}$ & $\begin{array}{c}2001- \\
2500\end{array}$ & $\begin{array}{c}2501- \\
3000\end{array}$ & $\begin{array}{c}3001- \\
3500\end{array}$ & $\begin{array}{c}3501- \\
4000\end{array}$ & $\begin{array}{c}4001- \\
4500\end{array}$ & $\begin{array}{c}4501- \\
5000\end{array}$ & $>5000$ & $\begin{array}{l}\text { \# Reporting } \\
\text { Affected } \\
\text { Employees }\end{array}$ \\
\hline Clark & 34 & 5 & 1 & 0 & c & 0 & 0 & 0 & 0 & 0 & 0 & 40 \\
\hline King & 287 & 31 & 6 & 3 & 3 & 3 & 1 & 1 & 0 & 0 & 4 & 338 \\
\hline Kitsap & 14 & 4 & 0 & 0 & $\mathrm{c}$ & 0 & 0 & 0 & 0 & 0 & 0 & 18 \\
\hline Pierce & 60 & 8 & 1 & 0 & c & 0 & 0 & 1 & 0 & 0 & 1 & 71 \\
\hline Snohomish & 33 & 6 & 2 & 0 & $\mathrm{c}$ & 0 & 0 & 0 & 0 & 0 & 1 & 42 \\
\hline Spokane & 51 & 8 & 0 & 2 & c & 0 & 0 & 0 & 0 & 0 & 0 & 61 \\
\hline Thurston & 59 & 2 & 2 & 1 & $\mathrm{c}$ & 0 & 0 & 0 & 0 & 0 & 0 & 64 \\
\hline Yakima & 11 & 1 & 0 & 0 & c & 0 & 0 & 0 & 0 & 0 & 0 & 12 \\
\hline Total & 549 & 65 & 12 & $\epsilon$ & 2 & 3 & 1 & 2 & 0 & 0 & 6 & 646 \\
\hline
\end{tabular}


Table 4 shows the number of employees reported by different size employers in each county. The 85 percent of worksites with 500 or fewer affected employees account for only 39 percent of affected employees. The eight largest worksites are one percent of the worksites but account for 28 percent of affected employees.

Table 4

Distribution of Number of Employers by Size of Employer

\begin{tabular}{|c|c|c|c|c|c|c|c|c|c|c|c|c|}
\hline County & $<500$ & $\begin{array}{l}501- \\
1000\end{array}$ & $\begin{array}{l}1001- \\
1500\end{array}$ & $\begin{array}{l}1501- \\
2000\end{array}$ & $\begin{array}{l}2001- \\
2500\end{array}$ & $\begin{array}{l}2501- \\
3000\end{array}$ & $\begin{array}{l}3001- \\
3500\end{array}$ & $\begin{array}{c}3501- \\
4000\end{array}$ & $\begin{array}{l}4001- \\
4500\end{array}$ & $\begin{array}{l}4501- \\
5000\end{array}$ & $>5000$ & $\begin{array}{c}\text { Number } \\
\text { Reporting } \\
\text { Affected } \\
\text { Employees }\end{array}$ \\
\hline Clark & 6,519 & 3,598 & 1,209 & 0 & 0 & 0 & 0 & 0 & c & 0 & 0 & 11,501 \\
\hline King & 53,751 & 21.428 & 8,029 & 5,599 & 4,144 & 8.544 & 3,150 & 3,852 & ( & 0 & 28,303 & 134,693 \\
\hline Kitsap & 2,627 & 2,286 & 0 & 0 & 0 & 0 & 0 & 0 & ( & 0 & 0 & 4,929 \\
\hline Pierce & 12,302 & 5,932 & 1.114 & 0 & 0 & 0 & 0 & 3,825 & ( & 0 & 16,000 & 39,865 \\
\hline Snohomish & 7,482 & 4,288 & 2.488 & 0 & 0 & 0 & 0 & 0 & . & 0 & 23,982 & 38,230 \\
\hline Spokane & 10,548 & 5,773 & 0 & 3.644 & 0 & 0 & 0 & 0 & ( & 0 & 0 & 21,025 \\
\hline Thurston & 11,387 & 1,670 & 2.498 & 1,750 & 0 & 0 & 0 & 0 & ( & 0 & 0 & 17,107 \\
\hline Yakima & & 770 & 0 & 0 & 0 & 0 & 0 & 0 & 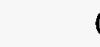 & 0 & 0 & 2,864 \\
\hline Total & 106.960 & 45.745 & 15.338 & 10.993 & 4.144 & 8.544 & 3.150 & 7.677 & r & 0 & 68.285 & 270.214 \\
\hline
\end{tabular}

Table 5 shows the CTR program descriptions filed in each county by different types of firms. The largest category of employers is government agencies. There are two reasons for this: one is that government employees tend to be concentrated in large worksites, particularly in Thurston County. The other is that every city and town with an affected employer within its boundaries is automatically an affected employer, even if it would not otherwise meet the requirements of the CTR law. Manufacturing is the second most common category of worksite, while construction is the least common, with only one affected employer. There may be other construction worksites with more than 100 employees, but the CTR law exempts them unless construction will last more than two years.

Table 5

Distribution of Worksites by Inclustry

\begin{tabular}{|c|c|c|c|c|c|c|c|c|c|}
\hline & Clark & King & Kitsap & Pierce & Snohomish & Spokane & Thurston & Yakima & Total \\
\hline $\begin{array}{l}\text { Agriculture \& food } \\
\text { processing }\end{array}$ & 1 & 13 & 0 & 2 & 0 & 0 & 3 & 3 & 22 \\
\hline $\begin{array}{l}\text { Non-metallic minerals } \\
\text { \& their products }\end{array}$ & 0 & 2 & 0 & 1 & 1 & 2 & 0 & 0 & 6 \\
\hline Construction & 0 & 0 & 1 & 0 & 0 & 0 & 0 & 0 & 1 \\
\hline Textiles \& clothing & 2 & 4 & 0 & 2 & 1 & 0 & 0 & 0 & 9 \\
\hline $\begin{array}{l}\text { Wood products. paper } \\
\text { \& printing }\end{array}$ & 10 & 12 & 1 & 7 & 3 & 1 & 0 & 0 & 34 \\
\hline Chemicals & 0 & 9 & 0 & 2 & 0 & 2 & 0 & 0 & 13 \\
\hline Primary metals & 1 & 1 & 0 & 2 & 0 & 3 & 0 & 0 & 7 \\
\hline Manufacturing & 9 & 70 & 2 & 4 & 10 & 13 & 1 & 2 & 111 \\
\hline $\begin{array}{l}\text { Transportation \& } \\
\text { communication }\end{array}$ & 5 & 49 & 0 & 12 & 7 & 4 & 4 & 1 & 82 \\
\hline Wholesale trade & 0 & 8 & 0 & 1 & 0 & 1 & 0 & 0 & 10 \\
\hline Retail trade & 0 & 26 & 0 & 0 & 1 & 1 & 0 & 0 & 28 \\
\hline $\begin{array}{l}\text { Finance. insurance \& } \\
\text { real estate }\end{array}$ & 1 & 49 & 0 & 4 & 3 & 7 & 2 & 0 & 66 \\
\hline Health care & 3 & 35 & 3 & 12 & 3 & 12 & 2 & 2 & 72 \\
\hline Education & 1 & 18 & 1 & 6 & 1 & 7 & 1 & 1 & 36 \\
\hline Other services & 0 & 56 & 3 & 2 & 3 & 3 & 0 & 1 & 68 \\
\hline Government & 8 & 73 & 7 & 14 & 11 & 9 & 53 & 5 & 180 \\
\hline Unknown & 0 & 62 & 0 & 0 & 0 & 0 & 0 & 0 & 62 \\
\hline
\end{tabular}

D-R9-32W6 
Research has shown that drive-alone commuting is more prevalent at worksites with free or low cost parking and a high ratio of employee parking spots to employees. Table 6 shows the fraction of worksites reporting that they provided employee parking. Most employers provide parking at the worksite. A smaller number provide parking in a lot or garage away from the worksite. Clark County worksites were not asked to supply this information, but five worksites reported it without prompting.

Table 6

\section{Worksites Reporting Employee Parking}

\begin{tabular}{lcccccc}
\hline & $\begin{array}{c}\text { Employer Provided } \\
\text { Parking }\end{array}$ & \multicolumn{2}{c}{$\begin{array}{c}\text { Onsite Employee } \\
\text { Parking }\end{array}$} & \multicolumn{2}{c}{$\begin{array}{c}\text { Offsite Employee } \\
\text { Parking }\end{array}$} \\
\hline \multicolumn{1}{c}{ County } & Sites & Percent & Sites & Percent & Sites & Percent \\
\hline Clark & 5 & 12.2 & 5 & 12.2 & 0 & 0 \\
King & 380 & 78.0 & 371 & 76.2 & 90 & 18.5 \\
Kitsap & 16 & 88.9 & 15 & 83.3 & 2 & 11.1 \\
Pierce & 67 & 94.4 & 66 & 93.0 & 13 & 18.3 \\
Snohomish & 40 & 90.9 & 40 & 90.9 & 7 & 15.9 \\
Spokane & 62 & 95.4 & 62 & 95.4 & 9 & 13.8 \\
Thurston & 52 & 78.8 & 50 & 75.8 & 12 & 18.2 \\
Yakima & 10 & 66.7 & 10 & 66.7 & 3 & 20.0 \\
$\quad$ Total & 632 & 78.3 & 619 & 76.7 & 135 & 16.7 \\
\hline
\end{tabular}

Table 7 shows the average number of employer provided parking spaces per employee reported in each of the counties. Clark County is not shown because of the unreported data.

Table 7

Parking Spaces per Employee

\begin{tabular}{lcc}
\hline County & $\begin{array}{c}\text { Parking Spaces Per Affected } \\
\text { Employee }\end{array}$ & $\begin{array}{c}\text { Number of } \\
\text { Worksites }\end{array}$ \\
\hline King & 0.90 & 340 \\
Kitsap & 0.73 & 18 \\
Pierce & 0.67 & 71 \\
Snohomish & 1.08 & 42 \\
Spokane & 1.32 & 60 \\
Thurston & 1.14 & 64 \\
Yakima & 0.69 & 12 \\
\hline
\end{tabular}

Table 8 shows the range of employer provided parking spaces per employee. Again. most of the zeros for Clark County are probably sites that did not report parking they have rather than sites with no parking. Except in King County, employers that provide parking for their employees tend to provide at least three stalls for every four employees. Not all employees are at a worksite during the same time every day. Some are on vacation, out sick, or on business trips, and some may work shifts other than eight-to-five. Employers generally can provide a parking space for every employee at work on any day with 75 to 80 percent as many stalls as employees. Most employers outside King County appear to be providing parking for all employees. Only in King County do many employers appear to provide parking for only a fraction of their employees. 
Table 8

Employer Provided Parking Spaces Per Employee

\begin{tabular}{lcccccccc}
\hline \multicolumn{1}{c}{ County } & Zero & 0 to $1 / 4$ & $1 / 4$ to $1 / 2$ & $1 / 2$ to $3 / 4$ & $3 / 4$ to 1 & 1 to $1 \& 1 / 2$ & $>1 \& 1 / 2$ \\
\hline Clark & 35 & 0 & 0 & 1 & 0 & 1 & 3 \\
King & 76 & 34 & 45 & 52 & 38 & 53 & 42 \\
Kitsap & 2 & 3 & 1 & 0 & 5 & 5 & 2 \\
Pierce & 4 & 2 & 4 & 4 & 17 & 25 & 15 \\
Snohomish & 3 & 1 & 1 & 2 & 7 & 18 & 10 \\
Spokane & 2 & 1 & 4 & 5 & 17 & 15 & 16 \\
Thurston & 13 & 5 & 2 & 10 & 10 & 15 & 9 \\
Yakima & 2 & 5 & 0 & -1 & 0 & 1 & 3 \\
\hline
\end{tabular}

Table 9 shows the availability of public parking for employees. This includes parking on the street and in lots and garages not operated by the employer. King County is the only one where more worksites report nearby pay public parking than nearby free public parking. The lower fraction of sites in Yakima and Snohomish counties reporting nearby public parking may indicate that affected sites in these counties are less likely to be located near city centers. Again, Clark County is not shown because employers there were not asked to provide this information.

Tabia 9

'Public Parking Near Affected Worksites

\begin{tabular}{lcccccc}
\hline County & $\begin{array}{c}\text { Sites With } \\
\text { Public Parking }\end{array}$ & $\begin{array}{c}\text { Percent of Sites } \\
\text { With Public } \\
\text { Parking }\end{array}$ & $\begin{array}{c}\text { Sites With Free } \\
\text { Public Parking }\end{array}$ & $\begin{array}{c}\text { Percent of Sites } \\
\text { With Free } \\
\text { Public Parking }\end{array}$ & $\begin{array}{c}\text { Sites With Pay } \\
\text { Public Parking }\end{array}$ & $\begin{array}{c}\text { Percent of Sites } \\
\text { With Pay Public } \\
\text { Parking }\end{array}$ \\
\hline King & 334 & 68.6 & 120 & 24.6 & 217 & 44.6 \\
Kitsap & 12 & 66.7 & 11 & 61.1 & 3 & 16.7 \\
Pierce & 38 & 53.5 & 37 & 52.1 & 14 & 19.7 \\
Snohomish & 17 & 38.6 & 16 & 36.4 & 4 & 9.1 \\
Spokane & 42 & 64.6 & 38 & 58.5 & 17 & 26.2 \\
Thurston & 52 & 78.8 & 46 & 69.7 & 23 & 34.8 \\
Yakima & 2 & 13.3 & 1 & 6.7 & 1 & 6.7 \\
$\quad$ State & 497 & 61.6 & 269 & 33.3 & 279 & 34.6 \\
\hline
\end{tabular}

The employer reporting forms generally asked about worksite features that can encourage commuters not to drive alone. These include transit service, sidewalks or bike trails. bicycle parking, clothes lockers and showers, and services such as restaurants and shopping within walking distance. Table 10 shows the fraction of worksites that reported a bus stop or ferry terminal within $1 / 4$ mile. Only a fraction of Pierce County and Yakima County worksites reported this information. With less than half of the worksites reporting, the Yakima percentage is suspect, but Yakima County does have a number of affected worksites outside the urban area. Thurston County is at the other extreme, with few affected worksites outside the Olympia-Lacy-Tumwater urban area.

Table 10

Transit Service to Affected Worksites

\begin{tabular}{lccc}
\hline \multicolumn{1}{c}{ County } & Bus or Ferry in $1 / 4$ Mile & Worksites Reporting & Percent Bus or Ferry in 1/4 Mile \\
\hline Clark & 28 & 31 & 90.3 \\
King & 379 & 442 & 85.7 \\
Kitsap & 14 & 17 & 82.4 \\
Pierce & 8 & 11 & 72.7 \\
Snohomish & 34 & 42 & 81.0 \\
Spokane & 57 & 61 & 93.4 \\
Thurston & 60 & 62 & 96.7 \\
Yakima & 5 & 12 & 41.7 \\
$\quad$ State & 585 & 678 & 86.3 \\
\hline
\end{tabular}


Table 11 shows accessibility by sidewalk, and Table 12 shows proximity to a bicycle trail or streets with marked bicycle lanes. The low number of worksites reporting this information makes the Yakima County and Pierce County percentages suspect. In the other counties. the fraction of worksites with sidewalks is probably a rough indicator of the split between urban and rural worksites.

Table 11

Worksites Reporting Sidewalk Access

\begin{tabular}{lccc}
\hline County & $\begin{array}{c}\text { Sites With Sidewalk } \\
\text { in 1/4 Mile }\end{array}$ & $\begin{array}{c}\text { Worksites Reporting } \\
\text { Clark }\end{array}$ & $\begin{array}{c}\text { Percent of Sites With } \\
\text { Sidewalk in 1/4 Mile }\end{array}$ \\
King & 21 & 27 & 77.8 \\
Kitsap & 405 & 487 & 83.2 \\
Pierce & 17 & 18 & 94.4 \\
Snohomish & 6 & 11 & 54.5 \\
Spokane & 33 & 42 & 78.6 \\
Thurston & 49 & 64 & 76.6 \\
Yakima & 59 & 65 & 90.8 \\
$\quad$ State & 5 & 5 & 100.0 \\
\hline
\end{tabular}

Less than $1 / 4$ of the worksites reported whether there were bike lanes or bike trails nearby. No sites reported this information in King County. Only eight reported it in Pierce County, and only two in Yakima County. Clark County employers were given the opportunity to provide this information but may not have been prompted for it. Even if the figures for the other counties are reliable, there is little. basis for cross county comparisons. The main lesson from this table is that a much lower fraction of worksites is served by dedicated bicycle lanes than by transit or sidewalks.

Table 12

Worksites Reporting Nearby Bike Lanes

\begin{tabular}{lccc}
\hline County & $\begin{array}{c}\text { Sites With Bike Trail } \\
\text { in 1/4 Mile }\end{array}$ & $\begin{array}{c}\text { Worksites Reporting } \\
\text { Clark }\end{array}$ & $\begin{array}{c}\text { Percent of Sites With Bike } \\
\text { Trail in 1/4 Mile }\end{array}$ \\
Kitsap & 2 & 13 & 15.4 \\
Pierce & 3 & 17 & 41.2 \\
Snohomish & 10 & 8 & 37.5 \\
Spokane & 6 & 41 & 24.4 \\
Thurston & 29 & 13 & 46.2 \\
Yakima & 2 & 62 & 46.8 \\
$\quad$ State & 59 & 2 & 100.0 \\
\hline
\end{tabular}

Table 13 shows the fraction of sites reporting bicycle parking. It appears that about 40 percent of affected worksites do not provide even minimal bicycle parking. Clark County employers did not report this information.

Table 13

Worksites Reporting Bicycle Parking

\begin{tabular}{lccc}
\hline \multicolumn{1}{c}{ County } & Sites With Bike Parking & Total Sites & Percent of Sites With Bike Parking \\
\hline King & 297 & 487 & 61.0 \\
Kitsap & 10 & 18 & 55.6 \\
Pierce & 42 & 63 & 66.7 \\
Snohomish & 19 & 42 & 45.2 \\
Spokane & 55 & 65 & 84.6 \\
Thurston & 40 & 65 & 61.5 \\
Yakima & 12 & 14 & 85.7 \\
\multicolumn{1}{c}{ State } & 475 & 754 & 63.0 \\
\hline
\end{tabular}


Table 14 shows the fraction of sites reporting that they have clothes lockers; and Table 15 shows the fraction of sites reporting that they have showers. No more than half of worksites provide shower and changing facilities that can be used by employees who bicycle or walk to work.

Table 14

Worksites Reporting Employee Lockers

\begin{tabular}{lccc}
\hline \multicolumn{1}{c}{ County } & Sites With Lockers & Total Sites & Percent of Sites With Lockers \\
\hline King & 220 & 487 & 45.2 \\
Kitsap & 5 & 18 & 27.8 \\
Pierce & 24 & 71 & 33.8 \\
Snohomish & 18 & 44 & 40.9 \\
Spokane & 43 & 65 & 66.2 \\
Thurston & 30 & 66 & 45.5 \\
Yakima & 7 & 15 & 46.7 \\
$\quad$ State & 348 & 766 & 45.3 \\
\hline \multicolumn{4}{c}{} \\
\multicolumn{4}{c}{ Table 15 } \\
\hline \multicolumn{1}{c}{ County } & Sites With Showers & Total Sites & Percent of Sites With Showers \\
\hline King & 261 & 487 & 53.6 \\
Kitsap & 8 & 18 & 44.4 \\
Pierce & 30 & 71 & 42.3 \\
Snohomish & 20 & 44 & 45.5 \\
Spokane & 45 & 65 & 69.2 \\
Thurston & 33 & 66 & 50.0 \\
Yakima & 6 & 15 & 40.0 \\
\multicolumn{1}{c}{ State } & 403 & 766 & 52.6 \\
\hline
\end{tabular}

Employees who must drive to run errands, to go shopping, or to go out for lunch, are more likely to commute in SOVs. Tables 16 and 17 show the fractions of worksites that reported having restaurants or shopping within 1/4 mile. Both fractions are lowest in Yakima. Clark. and Snohomish Counties. More worksites have restaurants nearby than have shopping nearby.

Table 16

Worksites Reporting Restaurants Nearby

\begin{tabular}{lccc}
\hline county & $\begin{array}{c}\text { Sites With Restaurant } \\
\text { in 1/4 Mile }\end{array}$ & Total Sites & $\begin{array}{c}\text { Percent of Sites With } \\
\text { Restaurant in 1/4 Mile }\end{array}$ \\
\hline Clark & 22 & 41 & 53.7 \\
King & 354 & 487 & 72.7 \\
Kitsap & 13 & 18 & 72.2 \\
Pierce & 51 & 71 & 71.8 \\
Snohomish & 26 & 44 & 59.1 \\
Spokane & 40 & 65 & 61.5 \\
Thurston & 52 & 66 & 78.8 \\
Yakima & 5 & 15 & 33.3 \\
$\quad$ State & 563 & 807 & 69.8 \\
\hline
\end{tabular}


Table 17

Worksites Reporting Shopping Nearby

\begin{tabular}{lccc}
\hline County & $\begin{array}{c}\text { Sites With Shopping } \\
\text { in 1/4 Mile }\end{array}$ & Total Sites & $\begin{array}{c}\text { Percent of Sites With } \\
\text { Shopping in 1/4 Mile }\end{array}$ \\
\hline Clark & 16 & 41 & 39.0 \\
King & 264 & 487 & 54.2 \\
Kitsap & 11 & 18 & 61.1 \\
Pierce & 36 & 71 & 50.7 \\
Snohomish & 21 & 44 & 47.7 \\
Spokane & 37 & 65 & 56.9 \\
Thurston & 35 & 66 & 53.0 \\
Yakima & 4 & 15 & 30.8 \\
$\quad$ State & 424 & 807 & 52.5 \\
\hline
\end{tabular}

When worksites are clustered together, émployees have a larger pool of potential ride-sharing partners. Denser areas also can justify better transit service. Table 18 shows the fraction of worksites that report having other employers located within 1/4 mile. Worksites in King County and Yakima County did not report this information. The Clark County data may be under-reported. Most affected worksites in the other counties do have other employers nearby.

Table 18

Worksites Near Other Employers

\begin{tabular}{lccc}
\hline County & $\begin{array}{c}\text { Sites With Other } \\
\text { Employers in 1/4 Mile }\end{array}$ & $\begin{array}{c}\text { Number of Sites } \\
\text { Reporting }\end{array}$ & $\begin{array}{c}\text { Percent of Sites With Other } \\
\text { Employers in 1/4 Mile }\end{array}$ \\
\hline Clark & 17 & 40 & 42.5 \\
Kitsap & 15 & 18 & 83.3 \\
Pierce & 58 & 65 & 89.2 \\
Snohomish & 35 & 43 & 81.4 \\
Spokane & 33 & 50 & 66.0 \\
Thurston & 58 & 66 & 87.9 \\
. State & 216 & 282 & 76.6 \\
\hline
\end{tabular}

Employees who do not work the day shift, who may have to work at more than one worksite. who are required to use their personal car for work related travel. or who are on call may find it difficult to commute other than by SOV. Table 19 Shows the fraction of worksites reporting that they have multiple shifts.

Table 19

Worksites with Multiple Shifts

\begin{tabular}{lccc}
\hline \multicolumn{1}{c}{ County } & $\begin{array}{c}\text { Sites With Multiple } \\
\text { Shifts }\end{array}$ & $\begin{array}{c}\text { Number of Sites } \\
\text { Reporting }\end{array}$ & $\begin{array}{c}\text { Percent of Sites With } \\
\text { Multiple Shifts }\end{array}$ \\
\hline Kitsap & 13 & 18 & 72.2 \\
Pierce & 56 & 70 & 80.0 \\
Snohomish & 31 & 43 & 72.1 \\
Spokane & 45 & 63 & 71.4 \\
Thurston & 37 & 66 & 56.1 \\
\multicolumn{1}{c}{ State } & 182 & 260 & 70.0 \\
\hline
\end{tabular}

Table 20 Shows the fraction of worksites reporting that some employees were required to work at more ${ }^{*}$ than one worksite. 
Tablè 20

Sites Where Some Employees also Work at Other Sites

\begin{tabular}{lccc}
\hline County & $\begin{array}{c}\text { Sites Where Employees } \\
\text { Work at Multiple Sites }\end{array}$ & $\begin{array}{c}\text { Number of Sites } \\
\text { Reporting }\end{array}$ & $\begin{array}{c}\text { Percent Work at } \\
\text { Multiple Sites }\end{array}$ \\
\hline Kitsap & 9 & 18 & 50 \\
Pierce & 24 & 70 & 34.3 \\
Snohomish & 22 & 43 & 51.2 \\
Spokane & 23 & 63 & 36.5 \\
Thurston & 30 & 66 & 45.5 \\
Yakima & - & 5 & 60.0 \\
State & 111 & 265 & 41.9 \\
\hline
\end{tabular}

Table 21 shows the fraction of worksites reporting that some employees were required to use their own vehicles for work trips.

Table 21.

Sites Where Employees Need Own Car

\begin{tabular}{lccc}
\hline County & $\begin{array}{c}\text { Sites Where Employees Need } \\
\text { Personal Vehicles for Work Trips }\end{array}$ & $\begin{array}{c}\text { Number of Sites } \\
\text { Reporting }\end{array}$ & $\begin{array}{c}\text { Percent of Sites Where } \\
\text { Employees Need Own Car }\end{array}$ \\
\hline Kitsap & 10 & 18 & 55.5 \\
Snohomish & 30 & 43 & 69.0 \\
Spokane & 37 & 62 & 59.7 \\
Thurston & 49 & 65 & 75.4 \\
Yakima & 2 & 3 & 66.7 \\
State & 109 & 147 & 74.2 \\
\hline
\end{tabular}

Table 22 shows the fraction of worksites reporting that some employees are on call.

Table 22

Worksites With Employees On Call

\begin{tabular}{lccc}
\hline County & $\begin{array}{c}\text { Sites With Employees on } \\
\text { Call }\end{array}$ & $\begin{array}{c}\text { Number of Sites } \\
\text { Reporting }\end{array}$ & $\begin{array}{c}\text { Percent of Worksites With } \\
\text { Employees on Call }\end{array}$ \\
\hline Clark & 0 & 40 & 0 \\
King & 0 & 5 & 0 \\
Kitsap & 16 & 18 & 88.9 \\
Pierce & 1 & 60 & 1.7 \\
Snohomish & 29 & 42 & 69.0 \\
Spokane & 49 & 62 & 79.0 \\
Thurston & 43 & 65 & 66.2 \\
Yakima & 1 & 2 & 50.0 \\
State & 139 & 294 & 47.3 \\
\hline
\end{tabular}

Employers were not asked how many affected employees worked at other sites, need their own car for work or are on-call. At most sites, they will make up only a fraction of the workforce. 


\section{SOV and VMT Rates}

The CTR law specifies that the substantive goals of the CTR program are to be reductions in SOV and VMT rates. The law also provides direction on how SOV and VMT rates are to be calculated, including credits for trips avoided and non-motorized trips.

\section{Definitions and Calculation Methods}

Initial SOV and VMT rates for the CTR zones were calculated from employee survey results or from modeled travel behavior based on information from the U.S. Census of Population. SOV and VMT rates for 1995, 1997, and 1999 will be calculated from survey results or from equivalent data submitted by employers. The Task Force developed formulas for calculating SOV and VMT from the employee surveys.

\section{SOV}

The Task Force developed two formulas for calculating SOV, one to be used for worksites with survey response rates of at least 70 percent. and the other to be used for worksites with lower response rates. Both formulas are based on survey responses to trips to work on Monday through Friday of the week

$\therefore$ preceding the survey. The first formula is:

SOV1 $=\frac{\text { SOV_TRIPS }- \text { CREDITS }}{\text { POTENTIAL_TRIPS }}$

where

CREDITS $=.20 *\left(D A Y S_{-}\right.$TELECOMMUTED + DAYS_BICYCLED +DAYS_WALKED

+COMPRESSED_WORK_WEEK_DAYS_OFF)

and

$$
\text { POTENTIAL_TRIPS }=5.0-C O M P R E S S E D \_W O R K_{-} W E E K_{-} D A Y S_{-} O F F
$$

This formula is the fraction of commute trips made in SOVs less the 20 percent credit for trips avoided and non-motorized trips.

For worksites that do not have a 70 percent response rate on the employee survey, SOV is to be calculated as:

$$
S O V 2=S O V 1 *\left(R E S P O N S E_{-} R A T E+.30\right)+1.0 *\left(.70-R E S P O N S E_{-} \text {RATE }\right)
$$

This combination of formulas assigns the measured worksite average SOV to non-respondents as long as they are 30 percent of the workforce or less. If more than 30 percent of employees at a worksite did not return surveys. the excess over 30 percent are assigned an SOV rate of 1.0 . 


\section{VMT}

The task force also developed two formulas for calculating VMT. VMT is based on trip distance multiplied by number of trips for which the commuter is responsible. One formula uses commute trip distances reported on the employee surveys. The other uses the zone average commute trip distance. The formulas are:

$V M T 1=\left(\left(S O V_{-} T R I P S+\left(C A R P O O L_{-} T R I P S / O C C U P A N C Y\right)-C R E D I T S\right) /\right.$ POTENTIAL_TRIPS $) *$ (HOME_TO_WORKSITE_MILES/SURVEY_RESPONSES)

Miles commuted in a carpool are divided up among the occupants, and miles commuted in a vanpool or bus are not counted. The formula includes a 20 percent credit for trips avoided or taken with a non motorized mode. The second formula is:

$V M T 2=\left(\left(S O V \_T R I P S+\left(C A R P O O L \_T R I P S / O C C U \dot{P} A N C Y\right)-C R E D I T S\right) /\right.$ POTENTIAL_TRIPS $) *$ ZONE_AVERAGE_COMMUTE_TRIP_MILES 


\section{Pre-CTR SOV and VMT}

SOV and VMT can be calculated for each worksite that surveyed employees based on the commute trip modes and trip lengths reported in the surveys. Table 23 shows the resulting weighted average SOV rate for each zone, where each worksite's rate is weighted by the number of employees. This calculation of SOV includes the credits for telecommuting, compressed work weeks, and non-motorized commuting.

\section{Table 23}

Average SOV Rates

\begin{tabular}{lcccc}
\hline \multicolumn{1}{c}{ Zone Name } & $\begin{array}{c}\text { Weighted Average } \\
\text { of SOV1 }\end{array}$ & Min of SOV1 & Max of SOV1 & Worksites \\
\hline Seattle Central Business District & 0.331 & 0.102 & 0.703 & 74 \\
Central Seattle & 0.501 & 0.149 & 0.737 & 22 \\
Kitsap County Zone & 0.585 & 0.203 & 0.971 & 32 \\
Bellevue Central Business District & 0.590 & 0.408 & 0.77 & 7 \\
North Central Seattle & 0.601 & 0.156 & 0.898 & 29 \\
Duwamish & 0.669 & 0.294 & 0.918 & 24 \\
North Seattle & 0.718 & 0.631 & 0.861 & 14 \\
South Seattle (Split Zones & 0.741 & 0.649 & 0.887 & 7 \\
North King County & 0.755 & 0.611 & 0.908 & 6 \\
Thurston County Zone 1 & 0.765 & 0.65 & 0.933 & 35 \\
Spokane County Zone 3 & 0.772 & 0.447 & 0.992 & 15 \\
Spokane County Zone 1 & 0.776 & 0.521 & 0.899 & 33 \\
Yakima County Zone 2 (outside Yakima city & 0.778 & 0.558 & 1.00 & 12 \\
limits) & & & & \\
South King County & 0.803 & 0.00 & 0.948 & 82 \\
East King County & 0.804 & 0.527 & 0.948 & 67 \\
Thurston County Zone 2 & 0.811 & 0.69 & 0.961 & 46 \\
Clark County Zone 1 (Urban) & 0.812 & 0.643 & 0.936 & 33 \\
Central Snohomish County Zone & 0.818 & 0.655 & 0.964 & 29 \\
Central Pierce County Zone (Tacoma-Fife Zone) & 0.828 & 0.512 & 0.987 & 57 \\
Clark County Zone 2 (Non-Urban) & 0.836 & 0.709 & 0.922 & 9 \\
Rural Pierce County Zone (Outer County) & 0.840 & 0.597 & 0.963 & 28 \\
Yakima County Zone 1 (within Yakima city & 0.849 & 0.756 & 0.948 & 13 \\
limits) & & & & \\
Southwest Snohomish County Zone & 0.862 & 0.744 & 0.92 & 16 \\
Rural King County & 0.868 & 0.749 & 0.969 & 8 \\
Spokane County Zone 2 & 0.881 & 0.634 & 0.951 & 29 \\
Rural Snohomish County & 0.889 & 0.813 & 0.939 & 6
\end{tabular}

Table 24 shows the distribution of worksite SOV rates within each zone. Zones are listed in order of increasing average SOV rate. 
Table 24

Worksite SOV Rates

\begin{tabular}{|c|c|c|c|c|c|c|c|c|c|c|}
\hline Zone Name & 0 to .10 & $\begin{array}{c}.10 \text { to } \\
.20 \\
\end{array}$ & $\begin{array}{l}.20 \text { to } \\
.30 \\
\end{array}$ & $\begin{array}{l}.30 \text { to } \\
.40\end{array}$ & $\begin{array}{l}.40 \text { to } \\
.50 \\
\end{array}$ & $\begin{array}{c}.50 \text { to } \\
.60 \\
\end{array}$ & $\begin{array}{c}.60 \text { to } \\
.70 \\
\end{array}$ & $\begin{array}{c}.70 \text { to } \\
.80 \\
\end{array}$ & $\begin{array}{c}.80 \text { to } \\
.90\end{array}$ & $\begin{array}{l}.90 \text { to } \\
1.00 \\
\end{array}$ \\
\hline Seattle Central Business & & 10 & 24 & 17 & .12 & 7 & 3 & 1 & & \\
\hline District & & & & & & & & & & \\
\hline Central Seattle & & 1 & 1 & 6 & 4 & 2 & 3 & 5 & & \\
\hline Kitsap County Zone & & & 2 & 2 & & & 2 & 8 & 12 & 6 \\
\hline Bellevue Central Business & - & & & & 1 & & 1 & 5 & & \\
\hline District & & & & & & & & & & \\
\hline North Central Seattle & & 1 & & 1 & 1 & 8 & 10 & 4 & 4 & \\
\hline Duwamish & & & 1 & 1 & 1 & 2 & 5 & 10 & 3 & 1 \\
\hline North Seattle & & & & & & & 3 & 7 & 4 & \\
\hline South Seattle (Split Zone) & & & & & & & 1 & 4 & 2 & \\
\hline North King County & & & & & & & 1 & 2 & 1 & 2 \\
\hline Thurston County Zone 1 & & & & & $\cdot$ & & 3 & 20 & 11 & 1 \\
\hline Spokane County Zone 3 & & & & & 1 & & 3 & 6 & 4 & 1 \\
\hline Spokane County Zone $\mathrm{i}$ & & & & & & 2 & 6 & 9 & 16 & \\
\hline $\begin{array}{l}\text { Yakima County Zone } 2 \\
\text { (outside Yakima city limits) }\end{array}$ & & & & & & 1 & 1 & 2 & 4 & 4 \\
\hline South King County & 1 & & & 2 & & 2 & 7 & 21 & 36 & 13 \\
\hline East King County & & & & & & 2 & 2 & 22 & 32 & 9 \\
\hline Thurston County Zone 2 & & & & & & & 1 & 19 & 20 & 6 \\
\hline Clark County Zone 1 (Urban) & & & & & & & ${ }^{4} 2$ & 7 & 17 & 7 \\
\hline Central Snohomish County & & & & & & & 4 & 4 & 16 & 5 \\
\hline Zone & & & & & & & & & & \\
\hline $\begin{array}{l}\text { Central Pierce County Zone } \\
\text { (Tacoma-Fife Zone) }\end{array}$ & & & & & & 1 & 3 & 11 & 27 & 15 \\
\hline $\begin{array}{l}\text { Clark County Zone } 2 \text { (Non- } \\
\text { Urban) }\end{array}$ & & & & & & & & 3 & 3 & 3 \\
\hline $\begin{array}{l}\text { Rural Pierce County Zone } \\
\text { Ruan }\end{array}$ & & & & & & 1 & 1 & 3 & 16 & 7 \\
\hline (Outer County) & & & & & & & & 3 & 10 & $f$ \\
\hline $\begin{array}{l}\text { Yakima County Zone } 1 \\
\text { (within Yakima city limits) }\end{array}$ & & & & & & & & 1 & 9 & 3 \\
\hline Southwest Snohomish Coun! & & & & & & & & 2 & 11 & 3 \\
\hline Zone & & & & & & & & & & \\
\hline Rural King County & & & & & & & & 2 & 3 & 3 \\
\hline Spokane County Zone 2 & & & & & & & 1 & 2 & 13 & 13 \\
\hline Rural Snohomish County & & & & & & & & & 4 & 2 \\
\hline
\end{tabular}

Table 25 shows weighted average daily VMT per employee, and Table 26 shows the distribution of worksite average VMT within each zone. This calculation includes the credit for telecommuting, compressed work weeks, and non-motorized commuting and excludes trips in buses and vanpools. Both tables are ordered by average VMT. 
Table 25

Average VMT

\begin{tabular}{|c|c|c|c|c|}
\hline Zone Name & $\begin{array}{l}\text { Weighted Average of } \\
\text { VMT1 }\end{array}$ & Min of VMT1 & Max of VMT1 & Worksites \\
\hline Seattle Central Business District & 6.0 & 2.527 & 12.625 & 74 \\
\hline $\begin{array}{l}\text { Yakima County Zone } 1 \text { (within Yakimi } \\
\text { city limits) }\end{array}$ & 7.3 & 5.411 & 9.533 & 13 \\
\hline Central Seattle & 7.8 & 1.914 & 12.542 & 22 \\
\hline Spokane County Zone 1 & 8.1 & 4.276 & 11.423 & 33 \\
\hline $\begin{array}{l}\text { Yakima County Zone } 2 \text { (outside } \\
\text { Yakima city limits) }\end{array}$ & 9.2 & 4.441 & 11.953 & 12 \\
\hline Clark County Zone 1 (Urban) & 9.5 & 6.094 & 15.11 & 33 \\
\hline North Central Seattle & 9.6 & 1.367 & 17.254 & 29 \\
\hline Kitsap County Zone & 9.6 & 5.869 & 15.25 & 32 \\
\hline North Seattle & 10.1 & 5.89 & 20.049 & 14 \\
\hline Bellevue Central Business District & 10.2 & 8.191 & 12.365 & 7 \\
\hline Spokane County Zone 2 & 11.0 & 6.4 & 12.94 & 29 \\
\hline Clark County Zone 2 (Non-Urban) & 11.1 & 3.107 & 15.787 & 9 \\
\hline Thurston County Zone 2 & 11.3 & 7.81 & 14.842 & 46 \\
\hline Thurston County Zone 1 & 11.5 & 8.126 & 16.345 & 35 \\
\hline $\begin{array}{l}\text { Rural Pierce County Zone (Outer } \\
\text { County) }\end{array}$ & 11.6 & 7.596 & 19.894 & 28 \\
\hline Southwest Snohomish County Zone & $\cdot 11.7$ & 8.888 & 14.225 & 16 \\
\hline $\begin{array}{l}\text { Central Pierce County Zone (Tacoma- } \\
\text { Fife Zone) }\end{array}$ & 11.8 & 5.091 & 21.193 & 57 \\
\hline North King County & 12.1 & 8.248 & 13.942 & 6 \\
\hline Duwamish & 129 & 5.48 & 19.469 . & 24 \\
\hline East King County & 12.9 & 7.512 & 18.984 & 67 \\
\hline Spokane County Zone 3 & 13.0 & 3.175 & 18.34 & 15 \\
\hline Central Snohomish County Zone & 13.4 & 9.615 & 20.382 & 29 \\
\hline South King County & 13.9 & 0 & 20.627 & 82 \\
\hline South Seattle (Split Zone) & 14.1 & 10.265 & 17.508 & 7 \\
\hline Rural King County & 15.2 & 6.563 & 19.678 & 8 \\
\hline Rural Snohomish County & 16.3 & 8.876 & 19.057 & 6 \\
\hline
\end{tabular}


Table 26

Worksite VMT

\begin{tabular}{|c|c|c|c|c|c|c|c|c|c|}
\hline Zone Name & VMTI & MT1 & IMT1 & VMT1 8 & VMT1 & VMTI & VMT1 & VMT1 & VMT1 \\
\hline & to 4 & to 6 & to 8 & to 10 & 10 to 12 & 12 to 14 & 14 to 16 & 16 to 18 & 18 to 20 \\
\hline Seattle Central Business District & 13 & 26. & 22 & 6 & 6 & 1 & & & \\
\hline $\begin{array}{l}\text { Yakima County Zone } 1 \\
\text { (within Yakima city limits) }\end{array}$ & & 3 & 6 & 4 & & & & . & \\
\hline Central Seattle & 1 & 6 & 4 & 5 & 3 & 2 & & & \\
\hline Spokane County Zone I & & 2 & 15 & 11 & 5 & & & & \\
\hline $\begin{array}{l}\text { Yakima County Zone } 2 \\
\text { (outside Yakima city limits) }\end{array}$ & & 2 & 3 & 3 & 4 & & & & \\
\hline Clark County Zone 1 (Urban) & & & 5 & 13 & 12 & 2 & 1 & & \\
\hline North Central Seattle & & 1 & 4 & 11 & 3 & 6 & 2 & 1 & \\
\hline Kitsap County Zone & & 1 . & 5 & 5 & 11 & 8 & 2 & & \\
\hline North Seattle & & 1 & 3 & 1 & 3 & 4 & 1 & & \\
\hline Bellevue Central Business District & & & & 2 & 3 & 2 & & & \\
\hline Spokane County Zone 2 & & & 1 & 8 & 15 & 5 & & & \\
\hline Clark County Zone 2 (Non-Urban) & 1 & & 1 & 1 & 3 & 2 & 1 & - & \\
\hline Thurston County Zone 2 & & & 2 & 12 & 18 & 12 & 2 & & \\
\hline Thurston County Zone 1 & & & & 5 & 14 & 15 & & 1 & \\
\hline $\begin{array}{l}\text { Rural Pierce County Zone (Outer } \\
\text { County) }\end{array}$ & & & 2 & 5 & 6 & 7 & 5 & 2 & 1 \\
\hline Southwest Snohomish County Zone & - & & & 3 & 7 & 5 & 1 & & \\
\hline $\begin{array}{l}\text { Central Pierce County Zone } \\
\text { (Tacoma-Fife Zone) }\end{array}$ & & 1 & 1 & 8 & 18 & 18 & 6 & 4 & \\
\hline North King County & & & & 1 & 2 & 3 & & & \\
\hline Duwamish & & 2 & & & 6 & 6 & 3 & 4 & 3 \\
\hline East King County & & & 2 & 5 & $\cdot 15$ & 22 & 17 & 5 & 1 \\
\hline Spokane County Zone 3 & 1 & 2 & & 1 & 5 & 1 & 4 & & 1 \\
\hline Central Snohomish County Zone & & & & 1 & 7 & 12 & 6 & 1 & 1 \\
\hline South King County & & 1 & 3 & 4 & 13 & $22^{\circ}$ & 27 & 7 & 3 \\
\hline South Seattle (Split Zone) & & & & & 3 & 2 & & 2 & \\
\hline Rural King County & & & 1 & 1 & & & 2 & 2 & 2 \\
\hline Rural Snohomish County & & & & 1 & & & 2 & & 3 \\
\hline
\end{tabular}

Tables 27 and 28 show the effect of the 20 percent credit for trips avoided and non-motorized trips on the calculation of SOV and VMT rates. Table 27 shows SOV rates for each zone with and without the credit. 
Table 27

SOV Rates with and without $20 \%$ Credit

\begin{tabular}{lccc}
\hline Zone Name & $\begin{array}{c}\text { SOV Without } \\
\text { Credit }\end{array}$ & $\begin{array}{c}\text { Weighted } \\
\text { Average SOV1 }\end{array}$ & Difference \\
\hline Seattle Central Business District & 0.347 & 0.331 & 0.017 \\
Central Seattle & 0.518 & 0.501 & 0.017 \\
Kitsap County Zone & 0.598 & 0.585 & 0.014 \\
Bellevue Central Business District & 0.602 & 0.590 & 0.012 \\
North Central Seattle & 0.616 & 0.601 & 0.016 \\
Duwamish & 0.671 & 0.669 & 0.003 \\
North Seattle & 0.740 & 0.718 & 0.022 \\
South Seattle (Split Zone) & 0.751 & 0.741 & 0.010 \\
North King County & 0.768 & 0.755 & 0.013 \\
THURSTON COUNTY ZONE 1 & 0.776 & 0.765 & 0.012 \\
Spokane County Zone 3 & 0.778 & 0.772 & 0.005 \\
Spokane County Zone 1 & 0.788 & 0.776 & 0.012 \\
Yakima County Zone 2 (outside Yakima city limits) & 0.784 & 0.778 & 0.006 \\
UNDEFINED ZONE & 0.810 & 0.799 & 0.011 \\
South King County & 0.812 & 0.803 & 0.009 \\
East King County & 0.814 & 0.804 & 0.009 \\
THURSTON COUNTY ZONE 2 & 0.822 & 0.811 & 0.012 \\
Clark County Zone 1 (Urban) & 0.824 & 0.812 & 0.012 \\
Central Snohomish County Zone & 0.825 & 0.818 & 0.006 \\
Central Pierce Criunity Zone (Tacoma-Fife Zone) & 0.836 & 0.828 & 0.008 \\
Clark County Zone 2 (Non-Urban) & 0.847 & 0.836 & 0.012 \\
Rural Pierce County Zone (Outer County) & 0.850 & 0.840 & 0.011 \\
Yakima County Zone 1 (within Yakima city limits) & 0.858 & 0.849 & 0.009 \\
Southwest Snohomish County Zone & 0.868 & 0.862 & 0.006 \\
Rural King County & 0.878 & 0.868 & 0.010 \\
Spokane County Zone 2 & 0.884 & 0.881 & 0.003 \\
Rural Snohomish County & 0.891 & 0.889 & 0.002 \\
\hline
\end{tabular}


Table 28 shows VMT rates for the zones with and without the 20 percent credit.

Table 28

VMT with and without $20 \%$ Credit

\begin{tabular}{lccc}
\hline Zone Name & $\begin{array}{c}\text { VMT Without } \\
\text { Credit }\end{array}$ & $\begin{array}{c}\text { Weighted } \\
\text { Average VMT1 }\end{array}$ & Difference \\
\hline Bellevue Central Business District & 10.42 & 10.18 & 0.24 \\
Central Pierce County Zone (Taçoma-Fife Zone) & 11.88 & 11.81 & 0.07 \\
Centrai Seattle & 7.86 & 7.84 & 0.02 \\
Central Snohomish County Zone & 13.54 & 13.42 & 0.12 \\
Clark County Zone 1 (Urban) & 9.65 & 9.52 & 0.13 \\
Clark County Zone 2 (Non-Urban) & 11.40 & 11.13 & 0.27 \\
Duwamish & 12.80 & 12.87 & -0.08 \\
East King County & 13.00 & 12.89 & 0.11 \\
Kitsap County Zone & 9.88 & 9.65 & 0.23 \\
North Central Seattle & 9.61 & 9.56 & 0.05 \\
North King County & 12.71 & 12.10 & 0.61 \\
North Seattle & 10.30 & 10.09 & 0.20 \\
Rural King County & 15.45 & 15.21 & 0.24 \\
Rural Pierce County Zone (Outer County) & 11.71 & 11.57 & 0.14 \\
Rural Snohomish County & 16.27 & 16.27 & -0.01 \\
Seattle Central Business District & 6.30 & 6.04 & 0.26 \\
South King County & 14.00 & 13.87 & 0.13 \\
South Seattle (Split Zone) & 14.21 & 14.13 & 0.08 \\
Southwest Snohomish County Zone & 11.81 & 11.72 & 0.10 \\
Spokane County Zone 1 & 8.21 & 8.13 & 0.08 \\
Spokane County Zone 2 & 11.06 & 11.03 & 0.03 \\
Spokane County Zone 3 & 13.07 & 12.99 & 0.08 \\
THURSTON COUNTY ZONE 1 & 11.67 & 11.48 & 0.19 \\
THURSTON COUNTY ZONE 2 & 11.44 & 11.26 & 0.17 \\
UNDEFINED ZONE & 12.03 & 11.87 & 0.17 \\
Yakima County Zone 1 (within Yakima city limits) & 7.33 & 7.27 & 0.06 \\
Yakima County Zone 2 (outside Yakima city limits) & 9.24 & 9.18 & 0.06 \\
\hline & & & \\
\hline
\end{tabular}

The 20 percent credit does not have a significant effect on the calculated base year SOV and VMT because only a small fraction of affected employees use the modes that get the credit. This can be seen in Table 31 below. 


\section{SOV and VMT Reduction Goals}

Tables 29 and 30 show the SOV and VMT reduction goals for each zone. Goals for zones marked with an asterisk $\left(^{*}\right)$ were based on modeled estimates of zone average SOV and VMT. The other Zones' goals are based on the employee survey results.

Table 29

SOV Goals

\begin{tabular}{lcccc}
\hline Zone & Base Year Value & 1995 Goal & 1997 Goal & 1999 Goal \\
\hline Clark County Zone 1 (Urban) & .888 & 0.755 & 0.660 & 0.577 \\
Clark County Zone 2 (Non-Urban) & .900 & 0.765 & 0.675 & 0.585 \\
North King County* & .85 & 0.72 & 0.64 & 0.55 \\
North Seattle* & .85 & 0.72 & 0.64 & 0.55 \\
North Central Seattle* & .74 & 0.63 & 0.56 & 0.48 \\
Central Seattle & .59 & 0.50 & 0.44 & 0.38 \\
Seattle Central Business District* & .43 & 0.37 & 0.32 & 0.28 \\
South Seattle (Split Zone)* & .83 & 0.71 & 0.62 & 0.54 \\
Duwamish* & .88 & 0.75 & 0.66 & 0.57 \\
East King County* & .85 & 0.72 & 0.64 & 0.55 \\
Bellevue Central Business District* & .81 & 0.69 & 0.61 & 0.53 \\
South King County* & .85 & 0.72 & 0.64 & 0.55 \\
Rural King County* & .90 & 0.77 & 0.68 & 0.59 \\
Kitsap County Zone* & .85 & 0.72 & 0.64 & 0.55 \\
Central Pierce County Zone (Tacoma-Fife & .85 & 0.72 & 0.64 & 0.55 \\
Zone)* & & & & \\
Rural Pierce County Zone (Outer County)* & .90 & 0.77 & 0.68 & 0.59 \\
Rural Snohomish County* & .82 & 0.70 & 0.62 & 0.53 \\
Southwest Snohomish County Zone* & .82 & 0.70 & 0.62 & 0.53 \\
Central Snohomish County Zone* & .80 & 0.68 & 0.60 & 0.52 \\
Spokane County Zone 1 & .7826 & 0.6652 & 0.5869 & 0.5087 \\
Spokane County Zone 2 & .8752 & 0.7439 & 0.6564 & 0.5689 \\
Spokane County Zone 3 & .7625 & 0.6481 & 0.5719 & 0.4956 \\
Thurston County Zone 1 & .763 & 0.65 & 0.57 & 0.50 \\
Thurston County Zone 2 & .811 & 0.69 & 0.61 & 0.53 \\
Yakima County Zone 1 (within Yakima city & .859 & 0.73 & 0.64 & 0.56 \\
limits) & & & & \\
Yakima County Zone 2 (outside Yakima city & .7502 & 0.6377 & 0.5627 & 0.4876 \\
limits) & & & & \\
\hline
\end{tabular}


Table 30

VMT Goals

\begin{tabular}{lcccc}
\hline Zone & Base Year Value & 1995 Goal & 1997 Goal & 1999 Goal \\
\hline Clark County Zone 1 (Urban) & 6.3 & 5.4 & 4.7 & 4.1 \\
Clark County Zone 2 (Non-Urban) & 6.9 & 5.9 & 5.2 & 4.5 \\
North King County* & 7.9 & 6.7 & 5.9 & 5.1 \\
North Seattle* & 8.2 & 7.0 & 6.2 & 5.3 \\
North Central Seattle* & 7.8 & 6.6 & 5.9 & 5.1 \\
Central Seattle* & 9.2 & 7.8 & 6.9 & 6.0 \\
Seattle Central Business District* & 6.8 & 5.8 & 5.1 & 4.4 \\
South Seattle (Split Zone)* & 9.6 & 8.2 & 7.2 & 6.2 \\
Duwamish* & 10.3 & 8.8 & 7.7 & 6.7 \\
East King County* & 9.3 & 7.9 & 7.0 & 6.0 \\
Bellevue Central Business District* & 9.2 & 7.8 & 6.9 & 6.0 \\
South King County* & 9.3 & 7.9 & 7.0 & 6.0 \\
Rural King County* & 9.0 & 7.7 & 6.8 & 5.9 \\
Kitsap County Zone* & 7.5 & 6.4 & 5.6 & 4.9 \\
Central Pierce County Zone (Tacoma-Fife & 7.2 & 6.1 & 5.4 & 4.7 \\
Zone)* & & & & \\
Rural Pierce County Zone (Outer County)* & 7.7 & 6.5 & 5.8 & 5.0 \\
Rural Snohomish County* & 7.7 & 6.5 & 5.8 & 5.0 \\
Southwest Snohomish County Zone* & 7.3 & 6.2 & 5.5 & 4.7 \\
Central Snohomish County Zone* & 8.5 & 7.2 & 6.4 & 5.5 \\
Spokane County Zone 1 & 8.21 & 6.98 & 6.16 & 5.34 \\
Spokane County Zone 2 & 10.70 & 9.10 & 8.03 & 6.96 \\
Spokane County Zone 3 & 12.13 & 10.31 & 9.10 & 7.88 \\
Thurston County Zone 1 & 11.47 & 9.7 & 8.6 & 7.5 \\
Thurston County Zone 2 & 11.29 & 9.6 & 8.5 & 7.3 \\
Yakima County Zone 1 (within Yakima city & 7.26 & 6.2 & 5.4 & 4.7 \\
limits) & & & & \\
Yakima County Zone 2 (outside Yakima city & 9.79 & 8.320 & 7.340 & 6.360 \\
limits) &. & & & \\
\hline
\end{tabular}

\section{Mode Splits and Commute Trip Lengths}

The employee surveys asked respondents to tell how they made their trip to work each day in the previous week. Table 31 shows the fraction of employees in each county who reported they used each commuting mode and the total number of commute trips survey respondents reported. All but two of the counties have SOV shares between 80 percent and 90 percent. Kitsap County has the lowest SOV rate, but this is due to the presence of a single large employer with limited parking. If that employer is excluded. Kitsap County does not stand out. King County's SOV share is lower than other counties, it has the highest transit share. and the second highest carpool share after Kitsap. Yakima County has the third highest carpool share combined with the lowest transit share. Carpooling is the second most frequently used mode except in King County, where transit is. 
Table 31

Employee Commute Modes Percentages

\begin{tabular}{lrrrrrrrrrr}
\hline County & SOV & Bike & Transit & Carpool & Other & Telecommute & Vanpool & Walk & $\begin{array}{c}\text { Commute } \\
\text { Trips }\end{array}$ \\
\hline Clark & 86.4 & 0.5 & 0.9 & 10.1 & 0.9 & 0.0 & 0.3 & 1.0 & 55437 \\
King & 63.8 & 0.9 & 16.0 & 15.1 & 1.1 & 0.2 & 0.7 & 2.1 & 354144 \\
Kitsap & 60.2 & 0.9 & 8.2 & 21.9 & 1.6 & 0.0 & 3.5 & 3.7 & 86903 \\
Pierce & 86.0 & 0.5 & 1.7 & 9.9 & 0.6 & 0.1 & 0.1 & 1.1 & 109630 \\
Snohomish & 84.9 & 0.2 & 1.2 & 11.2 & 1.1 & 0.1 & 0.6 & 0.7 & 75152 \\
Spokane & 82.5 & 0.6 & 2.9 & 11.4 & 0.7 & 0.0 & 0.6 & 1.3 & 94646 \\
Thurston & 81.5 & 1.0 & 2.3 & 11.2 & 1.2 & 0.1 & 0.9 & 1.7 & 84802 \\
Yakima & 84.2 & 0.4 & 0.5 & 12.7 & 0.7 & 0.0 & 0.0 & 1.5 & 18835 \\
$\quad$ Total & 73.6 & 0.7 & 8.2 & 13.7 & 1.0 & 0.1 & 0.9 & 1.8 & 879549 \\
\hline
\end{tabular}

The employee survey also asked respondents to tell the distance between their home and their worksite. Table 32 shows the average distance in each county.

Table 32

Average Commute Distances

\begin{tabular}{lc}
\hline \multicolumn{1}{c}{ County } & $\begin{array}{c}\text { Average Home to Work Distance } \\
\text { in Miles }\end{array}$ \\
\hline Clark & 11.5 \\
King & 15.1 \\
Kitsap & 14.2 \\
Pierce & 13.3 \\
Snohomish & 14.7 \\
Spokane & 11.7 \\
Thurston & 13.6 \\
Yakima & 9.1 \\
$\quad$ Total & 13.9 \\
\hline
\end{tabular}


Tables 33 and 34 show the same information for each zone.

Table 33

Employee Commute Modes by Zone Percentages

\begin{tabular}{|c|c|c|c|c|c|c|c|c|c|}
\hline ZONE & SOV & BIKE & TRANSIT & CARPOOL & OTHER & $\begin{array}{c}\text { TELE } \\
\text { COMMUTE } \\
\end{array}$ & $\begin{array}{l}\text { VAN } \\
\text { POOL } \\
\end{array}$ & WALK & $\begin{array}{c}\text { COMMUTE } \\
\text { TRIPS } \\
\end{array}$ \\
\hline $\begin{array}{l}\text { Seattle Central Business } \\
\text { District }\end{array}$ & 35.3 & 1.0 & 40.4 & 16.9 & 1.5 & 0.2 & 0.5 & 4.1 & 102.721 \\
\hline Central Seattle & $52.6-$ & 1.4 & 24.2 & 16.8 & 1.3 & 0.2 & 0.2 & 3.4 & 24,890 \\
\hline Kitsap County Zone & 60.1 & 0.9 & 8.2 & 21.9 & 1.6 & 0.0 & 3.5 & 3.7 & 86,903 \\
\hline $\begin{array}{l}\text { Bellevue Central } \\
\text { Business District }\end{array}$ & 60.7 & 0.5 & 11.9 & 23.1 & 0.9 & 1.1 & 0.8 & 1.0 & 7,583 \\
\hline North Central Seattle & 61.8 & 2.2 & 12.2 & 16.6 & 0.8 & 0.1 & 2.6 & 3.6 & 29,054 \\
\hline Duwamish & 67.6 & 0.8 & 9.5 & 19.5 & 0.8 & 0.0 & 1.4 & 0.5 & 18,293 \\
\hline North Seattle & 78.1 & 2.1 & 3.7 & 12.4 & 1.2 & 0.0 & $0.0^{\circ}$ & 2.4 & 14,074 \\
\hline $\begin{array}{l}\text { South Seattle (Split } \\
\text { Zone) }\end{array}$ & 76.5 & 0.7 & 5.1 & 15.4 & 0.9 & 0.0 & 0.7 & 0.8 & 9,483 \\
\hline North King County & 79.6 & 0.8 & 1.8 & 14.2 & 0.5 & 0.0 & 1.2 & 1.8 & 6,371 \\
\hline Thurston County Zone I & 78.4 & 1.1 & 3.3 & 12.2 & 1.3 & 0.2 & 1.3 & 2.3 & 35,849 \\
\hline Spokane County Zone 3 & 77.7 & 0.2 & 2.5 & 15.6 & 0.5 & 0.0 & 2.1 & 1.4 & 21,377 \\
\hline Spokane County Zone I & 80.7 & 1.0 & 4.7 & 10.6 & 0.9 & 0.0 & 0.2 & 1.9 & 42,880 \\
\hline $\begin{array}{l}\text { Yakima County Zone } 2 \\
\text { (outside Yakima city } \\
\text { limits) }\end{array}$ & 78.8 & 0.1 & 0.0 & 18.8 & 0.7 & 0.0 & 0.0 & 1.6 & 7,076 \\
\hline South King County & 83.4 & 0.4 & 1.3 & 12.6 & 1.0 & 0.1 & 0.7 & 0.5 & 79,848 \\
\hline East King County & 82.9 & 0.6 & 1.6 & 12.8 & 0.9 & 0.2 & 0.4 & 0.7 & 57,069 \\
\hline Thurston County Zone 2 & 84.2 & 1.1 & 1.4 & 10.6 & 1.0 & 0.1 & 0.5 & 1.1 & 40,036 \\
\hline $\begin{array}{l}\text { Clark County Zone } 1 \\
\text { (Urban) }\end{array}$ & 86.6 & 0.3 & 1.2 & 9.8 & 0.9 & 0.0 & 0.3 & 0.8 & 43,174 \\
\hline $\begin{array}{l}\text { Central Snohomish } \\
\text { County Zone }\end{array}$ & 82.9 & 0.3 & 1.6 & 12.1 & 1.4 & 0.1 & 0.8 & 0.8 & 44,641 \\
\hline $\begin{array}{l}\text { Central Pierce County } \\
\text { Zone (Tacoma-Fife } \\
\text { Zone) }\end{array}$ & 85.2 & 0.3 & 2.3 & 10.2 & 0.7 & 0.1 & 0.2 & 1.0 & 67,065 \\
\hline $\begin{array}{l}\text { Clark County Zone } 2 \\
\text { (Non-Urban) }\end{array}$ & 85.5 & 1.1 & 0.1 & 10.9 & 0.7 & 0.0 & 0.0 & 1.7 & 12,263 \\
\hline $\begin{array}{l}\text { Rural Pierce County } \\
\text { Zone (Outer County) }\end{array}$ & 87.4 & 0.7 & 0.6 & 9.5 & 0.5 & 0.1 & 0.0 & 1.2 & 42.565 \\
\hline $\begin{array}{l}\text { Yakima County Zone } 1 \\
\text { (within Yakima city } \\
\text { limits) }\end{array}$ & 87.4 & 0.5 & 0.8 & 9.0 & 0.8 & 0.0 & 0.0 & 1.5 & 11,759 \\
\hline $\begin{array}{l}\text { Southwest Snohomish } \\
\text { County Zone }\end{array}$ & 87.5 & 0.2 & 0.5 & 10.1 & 0.8 & 0.0 & 0.1 & 0.7 & 24,947 \\
\hline Rural King County & 89.4 & 0.8 & 0.3 & $8.5^{\prime}$ & 0.4 & 0.0 & 0.0 & 0.7 & 4,758 \\
\hline Spokane County Zone 2 & 88.3 & 0.4 & 0.6 & 9.7 & 0.6 & 0.0 & 0.0 & 0.3 & 30,389 \\
\hline Rural Snohomish & 88.7 & 0.1 & 0.1 & 9.5 & 0.3 & 0.1 & 0.7 & 0.4 & 5.564 \\
\hline
\end{tabular}


Table 34

Average Commute Distances by Zone

\begin{tabular}{lc}
\hline ZONE & $\begin{array}{c}\text { Average Home } \\
\text { to Work } \\
\text { Distance }\end{array}$ \\
\hline Seattle Central Business District & 14.9 \\
Central-Seattle & 13.2 \\
Kitsap. County Zone & 14.2 \\
Bellevue Central Business District & 14.9 \\
North Central Seattle & 13.9 \\
Duwamish & 16.9 \\
North Seattle & 13.0 \\
South Seattle (Split Zone) & 17.4 \\
North King County & 15.4 \\
Thurston County Zone 1 & 14.0 \\
Spokane County Zone 3 & 15.4 \\
Spokane County Zone 1 & 9.8 \\
Yakima County Zone 2 (outside Yakima city & 10.6 \\
limits) & \\
South King County & 16.2 \\
East King County & 14.9 \\
Thurston County Zone 2 & 13.1 \\
Clark County Zone 1 (Urban) & 11.1 \\
Central Snohomish County Zone & 15.4 \\
Central Pierce County Zone (Tacoma-Fife & 13.5 \\
Zone) & \\
Clark County Zone 2 (Non-Urban) & 12.7 \\
Rural Pierce County Zone (Outer County) & 13.1 \\
Yakima County Zone 1 (within Yakima city & 8.1 \\
limits) & \\
Southwest Snohomish County Zone & 12.9 \\
Rural King County & 16.9 \\
Spokane County Zone 2 & 11.9 \\
Rural Snohomish County & 17.4 \\
\hline &
\end{tabular}

King County has the highest average commute distance. The Seattle Central Business District has the lowest VMT but has a relatively high average commute distance. The ranking of counties and zones by commute distance and by VMT differ because VMT excludes transit trips, is weighted by occupancy for carpool trips, and includes credits for trips not taken. 


\section{First Year Program Descriptions}

Affected employers are required to file descriptions of their CTR programs with their local jurisdictions. This section describes the programs employers reported that they planned to implement in the first year of the program. The 1995 employer program reports will describe the programs employers actually implemented in 1994 and changes they plan to make for 1995.

\section{Coverage}

Affected employers are required to offer CTR programs to their affected employees. Most offer CTR to all employees or all full time employees. Of the 709 sites reporting which employees were eligible for their CTR program:

653 offered CTR to all employees,

22 offered CTR to some non-affected employees, and

34 offered CTR only to affected employees.

This is not surprising. Most employers would incur greater costs and problems in separating out those employees not eligible for a CTR program than they would in offering the program to all employees. $\dot{3}$

\section{Employee Transportation Coordinators}

All employers are required to appoint an Employee Transportation Coordinator (ETC). By the time they filed their initial program descriptions, 627 (78 percent) had appointed an ETC. The state Technical Assistance Team and the County Coordinators provided standardized training for ETCs. Only a fraction of the employer reports indicated whether ETCs had been trained. At those worksites that reported. information on ETC training:

193 of 234 ( 82.5 percent) had taken the State training, and

101 of 185 (54.6 percent) had taken other training.

\section{Information and Promotion}

Employers are required to post the ETC's name and phone number in a prominent place at each worksite. 518 of 627 ( 82.6 percent) reported having done so.

Employers have many options for disseminating information about their CTR programs to employees. Table 35 shows the fraction of employers reporting various methods of disseminating information about their CTR programs. The number of employers reporting differs across items because of differences in reporting forms. 
Table 35

Worksite CTR Information Dissemination

\begin{tabular}{lccc}
\hline Method & $\begin{array}{c}\text { Employers } \\
\text { Planning to Use }\end{array}$ & $\begin{array}{c}\text { Employers } \\
\text { Reporting }\end{array}$ & $\begin{array}{c}\text { Percent Planning } \\
\text { to Use }\end{array}$ \\
\hline Distribute handouts & 472 & 807 & 58.5 \\
Post on bulletin boards & 473 & 642 & 73.7 \\
Transportation events & 273 & 587 & 46.5 \\
Presentations at meetings & 313 & 626 & 50.0 \\
Newsletter articles & 366 & 807 & 43.4 \\
New employee orientations & 440 & 807 & 54.5 \\
Commuter Information Center & 74 & 188 & 39.4 \\
E-Mail & 142 & 807 & 17.6 \\
Other & 68 & 495 & 13.7 \\
\hline
\end{tabular}

\section{Carpooling and Vanpooling}

Employers have several methods they can use to encourage employees to carpool or participate in vanpools. They can provide preferential parking and subsidies for employee carpools. they can provide company vehicles. and they can operate or participare in a ridematching service. Table 36 shows programs employers plan to use to encourage ride sharing.

Table 36

Worksites with Ridesharing Programs

\begin{tabular}{lccc}
\hline Program & $\begin{array}{c}\text { Employers } \\
\text { Planning to Use }\end{array}$ & $\begin{array}{c}\text { Employers } \\
\text { Reporting }\end{array}$ & $\begin{array}{c}\text { Percent Planning to } \\
\text { Use }\end{array}$ \\
\hline Preferential parking for carpools & 352 & 790 & 44.6 \\
Preferential parking for vanpools & 206 & 757 & 27.2 \\
Carpool subsidies & 57 & 807 & 7.1 \\
Vanpool subsidies & 201 & 807 & 24.9 \\
Fleet vehicles for carpools & 32 & 807 & 4.0 \\
Fleet vehicles for vanpools & 14 & 807 & 1.7 \\
In-house ride-matching service & 145 & 807 & 18.0 \\
Public agency ride-matching service & 43 & 275 & 15.6 \\
Other ride-matching service & 5 & 160 & 3.1 \\
\hline
\end{tabular}

\section{Work Scheduling and Telecommuting}

Employees can eliminate work trips by working compressed work weeks or telecommuting. Employers that allow flexible schedules make it easier for employees to use transit or avoid peak traffic congestion. Table 37 shows the number of employers planning to allow alternative work schedules and telecommuting as part of their CTR programs.

\section{Table 37}

Worksites using Employee Scheduling in CTR

\begin{tabular}{lccc}
\hline Program & $\begin{array}{c}\text { Employers } \\
\text { Planning to Use }\end{array}$ & $\begin{array}{c}\text { Employers } \\
\text { Reporting }\end{array}$ & $\begin{array}{c}\text { Percent Planning } \\
\text { to Use }\end{array}$ \\
\hline Compressed work week & 323 & 807 & 30.0 \\
Allow flextime & 376 & 807 & 46.6 \\
Allow telecommuting & 177 & 807 & 21.9 \\
\hline
\end{tabular}




\section{Use of Company Vehicles}

Company fleet vehicles can be used to support CTR in several ways. Employers can use company vehicles for a guaranteed ride home program (GRH). Employers that provide fleet vehicles for work trips or for non-work trips during the work day make it easier for employees not to use their own vehicles for commuting. Employers can also provide company vehicles for carpools or vanpools. Table 38 shows the number of worksites planning to use fleet vehicles to support CTR.

Table 38

Worksites Using Company Vehicles for CTR

\begin{tabular}{lccc}
\hline Program & $\begin{array}{c}\text { Employers } \\
\text { Planning to Use }\end{array}$ & Employers Reporting & $\begin{array}{c}\text { Percent Planning to } \\
\text { Use }\end{array}$ \\
\hline Fleet vehicles for GRH & 35 & 588 & 6.0 \\
Fleet vehicles for work trips & 149 & 807 & 18.5 \\
Fleet vehicles for carpools or vanpools & 40 & 807 & .5 .0 \\
Fleet vehicles for non-work trips & 2 & 252 & 0.8 \\
\hline
\end{tabular}

\section{Parking Management}

Employers that provide parking for their employees can discourage SOV commuting and encourage use of other modes through the management of their parking facilities. They can reduce parking spaces and increase charges for SOVs and provide reserved parking with reduced charges for HOVs. Table 39 shows the number of worksites with parking management as part of their CTR programs.

Table 39

Worksite Parking Management

\begin{tabular}{lccc}
\hline Program & $\begin{array}{c}\text { Employers Planning to } \\
\text { Use }\end{array}$ & $\begin{array}{c}\text { Employers Reporting } \\
\text { Fees for employee parking }\end{array}$ & $\begin{array}{c}\text { Percent Planning to } \\
\text { Use }\end{array}$ \\
\hline Reserved parking for carpools & 38 & 506 & 17.4 \\
Reserved parking for vanpools & 352 & 790 & 44.6 \\
Lower parking fees for HOVs. & 206 & 757 & 27.2 \\
Fewer parking spaces for SOVs & 18 & 653 & 2.8 \\
\hline
\end{tabular}

\section{Facilities to Support Non-SOV. Commuting}

Employers can encourage use of commute modes other than SOVs by providing facilities to make using those modes easier or more convenient. Employers can provide covered parking for bicycles, showers and locker facilities for bicycle commuters and walkers, and loading areas for carpools and vanpools. Table 40 shows the number of worksites planning to provide facilities for non-SOV commuters.

Table 40

Worksite Non-SOV Facilities

\begin{tabular}{lccc}
\hline Program & $\begin{array}{c}\text { Employers } \\
\text { Planning to Use }\end{array}$ & $\begin{array}{c}\text { Employers } \\
\text { Reporting }\end{array}$ & $\begin{array}{c}\text { Percent. } \\
\text { Planning to Use }\end{array}$ \\
\hline Bicycle parking & 478 & 807 & 59.2 \\
Lockers or showers & 441 & 807 & 54.6 \\
Loading areas & 134 & 807 & 16.6 \\
\hline
\end{tabular}




\section{Subsidies and Incentives}

Table 41 shows the number of employers reporting that they will offer subsidies for non-SOV commuters as part of their CTR programs. Transit and vanpools are the modes that employers plan to subsidize most often. Only one worksite reported planning to offer a transportation allowance that could be used for any commuting mode.

Table 41

Worksites Offering Non-SOV Subsidies

\begin{tabular}{lccc}
\hline Program & $\begin{array}{c}\text { Employers } \\
\text { Planning to Use }\end{array}$ & $\begin{array}{c}\text { Employers } \\
\text { Reporting }\end{array}$ & $\begin{array}{c}\text { Percent } \\
\text { Planning to Use }\end{array}$ \\
\hline Bus subsidy & 239 & 807 & 29.6 \\
Ferry subsidy & 93 & 603 & 15.4 \\
Carpool subsidy & 57 & 807 & 7.1 \\
Vanpool subsidy & 201 & 807 & 24.9 \\
Bicycling subsidy & 58 & 765 & 7.6 \\
Walking subsidy & 35 & 765 & 4.6 \\
Transnortation allowance & 1 & 170 & $n .6$ \\
\hline
\end{tabular}

Table 42 shows the average subsidy amounts offered by employers who reported amounts.

Table 42

Average Non-SOV Subsidies

\begin{tabular}{lcc}
\hline Program & $\begin{array}{c}\text { Employers Reporting } \\
\text { Amount }\end{array}$ & $\begin{array}{c}\text { Average Amount } \\
\text { per Month }\end{array}$ \\
\hline Bus subsidy & 159 & $\$ 20.90$ \\
Ferry subsidy & 81 & $\$ 31.10$ \\
Carpool subsidy & 25 & $\$ 21.38$ \\
Vanpool subsidy & 122 & $\$ 27.54$ \\
Bicycling subsidy & 30 & $\$ 21.82$ \\
Walking subsidy & 12 & $\$ 26.79$ \\
\hline
\end{tabular}

\section{TMA Membership}

Eighty-six worksites reported that they belonged to a Transportation Management Association. 


\section{Next Steps}

This report covers commuting behavior before employers implemented CTR programs and the programs employers planned to implement. During the first half of 1995, employers will be filing new annual reports and conducting new employee surveys or collecting equivalent information on their employees commuting behavior. The results of the 1995 surveys will be used to determine whether the SOV and VMT reduction targets have been met and to estimate the impacts of the CTR program.

The CTR Task Force will report to the legislature in December 1995. That report will present the first year program results, and the program changes employers plan as they work to reach the 1997 and 1999 goals. That report also will contain the Task Force's evaluation of the CTR program and any recommendations the Task Force may have for changes in the law.

Employers will continue to file annual reports with their local jurisdictions, and they will survey employees or collect equivalent data in 1997 and 1999. This information will be used to determine whether the 1997 and 1999 goals have been met. Employers who wish to may survey their employees in 1996 and 1998 to gauge their progress toward meeting the goals and estimate the effectiveness of particular program elements.

The Task Force will make its second report to the legislature in December 1999. At that time, the Task Force will report on whether the 1997 and 1999 goals were met. The Task Force also will recommend whether the CTR program should be extended or allowed to sunset, or whether it should be replaced with some other type of program. 